\title{
Neanderthal diets in central and southeastern Mediterranean Iberia
}

\author{
Domingo C. Salazar-García a,b,c,*, Robert C. Power ${ }^{\text {a }}$, Alfred Sanchis Serra ${ }^{\mathrm{d}}$, \\ Valentín Villaverde ${ }^{\mathrm{c}}$, Michael J. Walker ${ }^{\mathrm{e}}$, Amanda G. Henry ${ }^{\mathrm{a}}$ \\ ${ }^{a}$ Research Group on Plant Foods in Hominin Dietary Ecology, Max-Planck Institute for Evolutionary Anthropology, Leipzig, Germany \\ ${ }^{\mathrm{b}}$ Department of Human Evolution, Max-Planck Institute for Evolutionary Anthropology, Leipzig, Germany \\ ${ }^{\mathrm{c}}$ Departamento de Prehistoria y Arqueología, Universitat de València, València, Spain \\ ${ }^{\mathrm{d}}$ Museu de Prehistòria de València, Servei d'Investigació Prehistòrica, Diputació de València, València, Spain \\ ${ }^{\text {e } D e p a r t a m e n t o ~ d e ~ Z o o l o g i ́ a ~ y ~ A n t r o p o l o g i ́ a ~ F i ́ s i c a, ~ U n i v e r s i d a d ~ d e ~ M u r c i a, ~ M u r c i a, ~ S p a i n ~}$
}

\section{A R T I C L E I N F O}

Article history:

Available online 18 June 2013

\begin{abstract}
A B S T R A C T
During recent decades, Neanderthal diet has been a major research topic in palaeoanthropology. This has been accelerated by the maturation of different techniques, which have produced a plethora of new information. However, this proliferation of data has led to confusing and contradictory results. Furthermore, most of the ecological dietary studies have been carried out on specimens drawn from different time periods and regions, almost exclusively those characterized by cold, open environmental conditions. Subsistence models based on these fragmentary data have been applied to Neanderthals living in a variety of different regions and environments, even though their dietary strategies may have been as variable as regions they inhabited. In this paper we integrate different dietary approaches (studies of the zooarchaeology, stable isotopes and plant remains) from the central and southeastern Mediterranean coast of Iberia in order to develop a broader and more complex picture of Neanderthal diet in different Mediterranean environmental conditions. Our results suggest that there may have been some minor dietary variation due to climatic or environmental differences, but that Neanderthal diet focussed on large terrestrial game, supplemented by plant foods when these were available.
\end{abstract}

(c) 2013 Elsevier Ltd and INQUA. All rights reserved.

\section{Neanderthal dietary ecology}

The dietary behaviours of Neanderthals and the relationship between their diet and their social organization, technological abilities, and even their eventual disappearance, have been hotly debated in the anthropological literature. Examining the diets of Neanderthals requires the synthesis of data that have been collected by numerous researchers over the last 150 years. In many cases, the differences between Neanderthal and early modern human diets have been emphasized, at the expense of cogent discussion of the variation within each group. Early modern humans lived in a wide variety of environmental contexts and likely pursued a variety of behaviours throughout this range of environments. The exclusively Eurasian distribution of Neanderthals did

\footnotetext{
* Corresponding author. Research Group on Plant Foods in Hominin Dietary Ecology, Max-Planck Institute for Evolutionary Anthropology, Deutscher Platz 6, 04103 Leipzig, Germany.

E-mail addresses: domingo_carlos@eva.mpg.de, domingocarlos.salazar@uv.es (D.C. Salazar-García).
}

not include as many environments, but neither was it the exclusively cold Arctic climate that many have supposed it to be. A more detailed examination of the Neanderthal range and the effects of shifting global climates reveals that this group would have been exposed to a diverse range of environments (Hoffecker, 2009; MacDonald et al., 2009). Just as modern human dietary behaviour likely varied with environments, so, too, can we predict that Neanderthals had different diets in different environments.

Our understanding of the diets of Neanderthals comes from three main lines of evidence. The first is the study of the human remains themselves, including the isotope signal recorded in their bones, the microwear on their teeth, and how factors of their lifehistory are related to diet. The second line of evidence includes the study of the remains of their food, in the form of animal and plant remains preserved at their sites. The third type of evidence comprises archaeological remains in the forms of tools and material culture and how these are related to food procurement and processing. This variety of dietary information is often confusing and, in places, contradictory. Data from different geographical areas and from different research methods provide different details about Neanderthal diets. However, when all of the data is examined 
rather coarsely, it appears likely that, generally-speaking, Neanderthals had a narrow diet and focused their attentions on large game, whereas a wider variety of foods characterized the diet of early modern humans.

The details of exactly how the diet changed, and why, are still a subject of considerable debate. Several researchers have used ethnographic analogues and applications of "dietary ecology" models in attempts to relate Neanderthal diet to other aspects of their behaviour. In general, these theories look for some limiting factor in the environment that determines how well an individual or species can acquire food and reproduce. These factors can be calories, other nutrients, or other aspects like time spent foraging or location of foraging areas. The models most commonly applied to Neanderthals and early modern humans are based on optimizing caloric intake. O'Connell (2006) suggested that because of their low-density populations, Neanderthals were able to focus almost exclusively on highly-ranked prey. In contrast, early modern humans living in Africa likely consumed a wider variety of animal foods, due in part to over-hunting of preferred prey as a result of increasing density of the human population. By about $50 \mathrm{ka}$, when modern humans moved into Eurasia, they likely competed with Neanderthals for large game. Moreover, they had developed new tool technologies (e.g. Bird and O'Connell, 2006) and new social structures (e.g. Kuhn and Stiner, 2006; Stiner and Kuhn, 2009) that allowed them to glean more food from the environment than did Neanderthals. Caught between competitive pressure from modern human groups and a worsening climate that preceded the Last Glacial Maximum, Neanderthals were no longer able to acquire sufficient calories from these diminishing supplies of large game. However, calories may have only been part of the explanation. Hockett and Haws $(2003,2005)$ have suggested that a wider diet would have provided more essential nutrients including vitamins and minerals. This increased nutritional quality lead to decreased mortality among pregnant females and infants in modern humans, which allowed them to reproduce at higher frequencies and outcompete Neanderthals.

A merit of these kinds of modelling approaches is that they attempt to take a variety of confusing and conflicting data and create a coherent summary. However, in most cases these dietary models have been applied with a very broad brush, potentially obscuring a large amount of regional variation in diet. Changing climate, population pressure, and other factors can strongly influence the dietary choices that a foraging group makes. Here we concentrate specifically on the dietary data from the Mediterranean coast of central and southeastern Iberia to illustrate how, in more temperate European environments, our picture of Neanderthal dietary breadth differs from the models such as those described above, which are based on evidence from both colder and more northern regions. In particular, Mediterranean Iberia is noteworthy because of the high density of Neanderthal sites and the abundance of its archaeological, faunal, and human remains during the Middle and Late Pleistocene periods.

\section{Iberia as an ecological region compared to other Neanderthal habitats}

The environment of Iberia presents an opportunity to study Neanderthal behaviour in a region defined by warmer temperatures, higher rainfall, and unique habitats compared to most of Europe. The region has long been the focus of palaeoenvironmental research, particularly because it was a refugium during several different glacial periods for temperate and Mediterranean flora and fauna (Hewitt, 1999; Barroso et al., 2006c; Gómez and Lunt, 2007). Even today, southeastern Iberia is considered a biodiversity hotspot (Mota et al., 2002; Carrión et al., 2003). Though these clement ecosystems were considerably more widespread across Europe during interglacial periods (Wenzel, 2007), the diversity and longevity of temperate forest ecosystems late into the Middle Pleistocene in southeastern Iberia distinguishes the ecological potential of this European subregion.

The environmental characteristics of the region have been reconstructed by palynological studies at cave sites occupied by Neanderthals, both inland and near the coast. Pines, evergreen oaks and deciduous oaks are widespread (Carrión et al., 2003). Open grasslands are implied by Poaceae and Chenopodiaceae, with stands of pines (Pinus nigra and Pinus sylvestris) co-existing and in constant progression or regression with an evergreen-forested fringe area of oak (Quercus sp.), juniper (Juniperus sp.) and wild olive tree (Olea sylvestris). Overall, the landscape appears to have included a mosaic of patchy sub-habitats, containing a Mediterranean flora, sclerophyllous shrubs (Phillyrea sp., Rhamnus sp., Myrtus sp., Lonicera sp., etc.), and typical "garrigue" or "matorral" plants (Cistus sp., Helianthemum sp., Ononis sp., Lamiaceae, etc.) (Carrión, 1992; Badal et al., 2012). At the Murcian coastal site of Sima de las Palomas del Cabezo Gordo (55-42 ka: Walker et al., 2012) the tree pollen points to damp-temperate conditions (very different from present-day high levels of evaporo-transpiration with fewer than $200 \mathrm{~mm}$ of annual rainfall) because pines (Pinus nigra, Pinus halepensis, or Pinus pinea), evergreen oaks (Quercus ilex, Quercus rotundifolia, Quercus coccifera), and deciduous oaks (Quercus faginea, Quercus canariensis, or Quercus pyrenaica) were accompanied by common hazel (Corylus avellana), ash (Fraxinus), strawberry tree (Arbutus unedo), box (Buxus), and birch (Betula cf. celtiberica). Nearby coastal saltpans and marshes are indicated by Chenopodiaceae, boxthorn (Lycium) and paternostrera (Withania frutescens), while thermophytes such as dogbane (Periploca angustifolia) or red spike thorn (Maytenus europaeus) that readily succumb to frost imply that the mean annual temperature at Sima de las Palomas was much like today, perhaps barely $2 \mathrm{C}^{\circ}$ lower (Carrión et al., 2003; Jennings et al., 2011). It is nevertheless likely that elsewhere mean annual temperatures might well have fallen to $10^{\circ} \mathrm{C}$ below present values, particularly on high ground away from the coast or in more northerly latitudes around the central Mediterranean region of Iberia (Badal et al., 2012).

The presence of warmer, wetter, and more diverse mosaic habitats is unusual, and no longer common in the area. The persistence of these mild climatic conditions in southern Iberia has been linked to the late survival of Neanderthals in this region (Finlayson et al., 2006; Sepulchre et al., 2007; Finlayson, 2008). It is likely that the environment provided a patchwork of localities where rainfall and warm or mild conditions maintained resourcerich habitats (Jennings et al., 2011) where Neanderthals may have had access to foods that were unavailable in other areas of Europe, particularly during cold periods. And, although we know that plant foods were available throughout the Neanderthal range in western Eurasia (Hardy, 2010), palaeoenvironmental evidence suggests the climatic conditions of southeastern coastal Iberia supported abundant edible plant foods in excess of more northern regions. Crucially, plant foods would have been found in denser concentrations, thus rendering higher energy returns compared to further north, east and inland.

\section{The Middle Palaeolithic in central and southeastern Mediterranean Iberia}

\subsection{Archaeological context and evidence}

To understand better how Neanderthals used the unique environment of central and southeastern Mediterranean Iberia, we rely on the data collected from archaeological excavations in the area. 
These data consistently show that the region was heavily populated during the Middle Palaeolithic and provide the first evidence of Neanderthal's dietary behaviour.

Neanderthal remains and Middle Palaeolithic archaeological and palaeontological finds in the Mediterranean region of Iberia were first discovered in the 19th century, and include several important fossils, notably the Forbes' Quarry skull from Gibraltar and the Banyoles mandible from Gerona. One of the first discoveries of Palaeolithic material from the central Mediterranean region was described by J. Vilanova i Piera in 1872, at the site of Cova Negra in Xàtiva, Valencia. More than 80 sites with Middle Palaeolithic levels are known in the area formed by Valencia (Fernández Peris and Villaverde, 2001) and Murcia (Zilhão and Villaverde, 2008). Some that have been excavated recently contain abundant stratified archaeological deposits (Fig. 1); important sites include Cova del Bolomor in Tavernes de Valldigna, Valencia (Fernández Peris, 2007), Cova Negra in Xàtiva, Valencia (Villaverde, 2006), Abrigo de la Quebrada in Chelva, Valencia (Villaverde et al., 2008, 2012; Eixea et al., 2011), Cova Foradada in Oliva, Valencia (Campillo et al., 2002), Abric del Salt and Abric del Pastor in Alcoi, Alicante (Galván et al., 2006, 2008; Gómez de la Rua et al., 2010), Cova de Dalt del Tossal de la Font in Vilafamés, Castellón (Olària et al., 20042005), Cueva Antón in Mula, Murcia (Zilhão et al., 2010), Sima de las Palomas del Cabezo Gordo in Torre Pacheco, Murcia (Walker et al.,

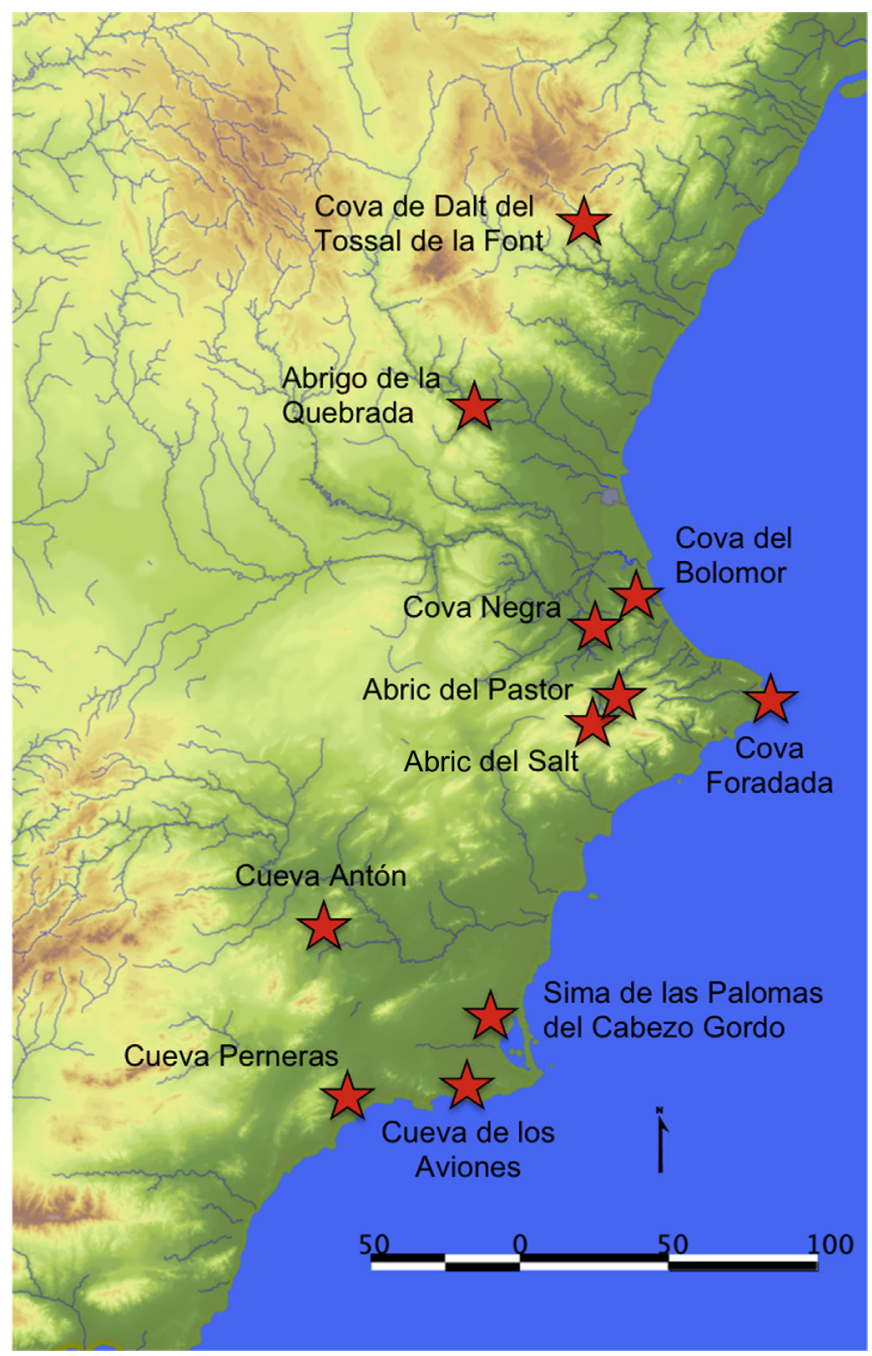

Fig. 1. Main Middle Palaeolithic sites from central and southeastern Mediterranean Iberia.
2012), Cueva Perneras in Lorca, Murcia (Montes Bernárdez, 1991) and Cueva de los Aviones in Cartagena, Murcia (Montes Bernárdez, 1989). Though several other sites are known, they are less wellpublished, usually with poor stratigraphical and chronological control. The abundance of archaeological sites suggests that the Iberian Mediterranean region area was widely populated during the Middle Palaeolithic.

Although only a few sites have Neanderthal skeletal remains, these provide important data about their diets, as discussed below. Human fossils have been recovered from Cova de Dalt del Tossal de la Font (Arsuaga and Bermúdez de Castro, 1984; Saladié et al., 2010), Cova Negra (Arsuaga et al., 1989, 2006), Abric del Salt (Galván et al., 2001), Cova Foradada (Campillo et al., 2002) and Sima de las Palomas (Walker et al., 2012).

The archaeological record can help elucidate how the unique environments of the region were used. The area was settled early on, at least by MIS 21, as indicated by the Middle Paleolithic-like assemblage with small proto-Mousterian flakes and preNeanderthal fossils found at Cueva Negra del Estrecho del Rio Quipar (Scott and Gibert, 2009; Walker et al., 2013). Later, classic Middle Paleolithic sites can be divided into at least two phases. An Early Middle Palaeolithic (prior to MIS 5) mainly known by Cova del Bolomor sequence, and a Classic Middle Palaeolithic (between MIS 5 and MIS 3) ending around $32.3 \mathrm{ka}$ at the latest, based on the absolute radiometric dates from Cueva Antón. The sequences at Cova Negra and Cova del Bolomor confirm the occupation of the region during both phases. However, because these sites subsume large periods of time, it is not possible to confirm that the occupation was continuous. Based on the number of sites and findings, it appears there was a higher human presence in the region during MIS 4 and 3.

The two phases differ mostly in the size and morphology of the knapped blanks used. During the Early Middle Palaeolithic, the flakes are smaller and thicker and are usually heavily retouched, denticulate blades are common, and most tools are made on discoid cores. Limestone flakes are present during the first phase of Cova del Bolomor (level XII), with absence of bifacial tools and cleavers. During the Late Middle Palaeolithic, the blanks are less thick and the Levallois technique becomes common (especially from MIS 4 onwards). Quina-type knapping and associated thick side scrapers appear in lower levels at Cova Negra, while discoid knapping is dominant at the lower levels of Abrigo de la Quebrada. Points are more abundant during the Late Middle Palaeolithic, especially during MIS 4 and 3. Additionally, many of these points show evidence of use wear and impact marks, at much higher levels than on Early Middle Palaeolithic points.

The presence of impact marks is a significant sign of the dietary behaviour of these later Neanderthals. These marks have been found on points from Cova Negra, Abrigo de la Quebrada (Fig. 2) and Abric del Pastor (Villaverde, 2006; Galván et al., 2007-2008; Villaverde et al., 2012), and suggest increased reliance on hunting during the Classic Middle Palaeolithic. These data are coincident with evidence from other Middle Palaeolithic sites in northern Iberia (Rios, 2006), France (Villa and Lenoir, 2006) and Italy (Villa et al., 2009), confirming the importance of hunting weapons and meat acquisition.

Lithic use-wear studies on other types of stone tools suggest a diversity of tool use. Side scrapers from Cova Negra (Moriel, 1985) preserve evidence of heavy use on wood. Tools from Abric del Salt (Rodríguez et al., 2002) suggest woodworking, leather preparation and animal processing and consumption. At Abrigo de la Quebrada, the analysis of some small pieces that are the result of microlevallois technique suggests that these small flakes were used instead of formal retouched tools, and furthermore, that 

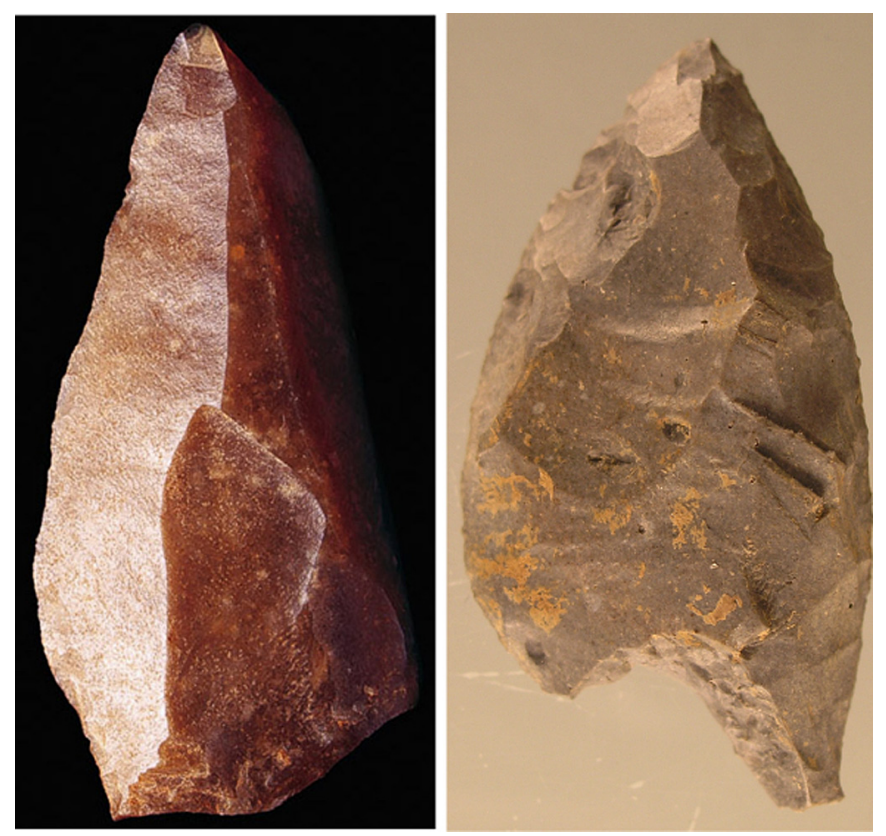

Fig. 2. Impact marks on stone points from Abrigo de la Quebrada.

Neanderthals at this site had a diversified lithic production that was well adapted to seasonal occupations (Villaverde et al., 2012).

The raw material used to make these tools also provides us information about how the Neanderthals used their landscape. Flint is generally dominant, but at the upper levels (II-V) of Abrigo de la Quebrada there is considerable variation, with quartzite and limestone also being important. At most sites the raw material is local (Molina et al., 2010; Eixea et al., 2011). However, a few sites have tools made on raw material from distant sources. Some of the material found at Abrigo de la Quebrada (Eixea et al., 2011) comes from sources more than $100 \mathrm{~km}$ from the site. This pattern has also been observed in flint from Cova Negra and Abric del Salt. These data indicate high territorial mobility of Neanderthal groups, and, combined with evidence from use of animal resources (see point 4), are compatible with the high mobility models proposed for the region based on the alternation of human and carnivore occupations at Cova Negra (Villaverde et al., 1996).

Other archaeological evidence also provides information about diets and landscape use. The use of fire, indicated by the presence of hearths in many of the sites, was common and widespread during this period (Fernández-Peris et al., 2012). In addition, there is evidence for the use of fire at Cueva Negra del Estrecho del Río Quipar that is older than $780 \mathrm{ka}$, possibly corresponding to MIS 21 (Walker et al., 2013), suggesting that fire use has a long history in this area. The studies of hearths and their spatial distribution at the sites have been published for Cova Negra (Soler, 2003), Abric del Salt (Sistiaga et al., 2011), Abrigo de la Quebrada (Eixea et al., 2013), and Cova del Bolomor (Sañudo and Fernández Peris, 2007). Knapping and consumption activities are associated to these hearths, which in most of the cases appear in levels that accumulate several superimposed occupations, indicating that fires were repeatedly burned in the same areas and formed palimpsests.

Finally, the archaeological material from the Mediterranean coast of Iberia also includes evidence that Neanderthals engaged in symbolic behaviours usually associated with modern humans. Perforated and pigment-stained marine shells (Acanthocardia, Glycimeris and Pecten) that have been attributed to symbolic use as body ornaments were recovered at Cueva de los Aviones and Cueva Antón (Zilhão et al., 2010).
In summary, the archaeological evidence suggests that in the Middle Palaeolithic, Neanderthal occupation in the central and southeastern Mediterranean coastal region of Iberia was not continuous in time, but achieved a moderate to high density at least during some stages of MIS 3. Neanderthals hunted, processed plants, and had controlled use of fire. They may have had complex mobility strategies, where they engaged in a mix of long-distance travel and local or seasonal occupation of sites. Finally, in a few places they may have begun to develop symbolic behaviours. However, since these data are limited on diet itself, we turn to three lines of evidence (zooarchaeology, stable isotopes, and plant microremains) that give direct information on Neanderthal diets.

\section{The zooarchaeological evidence: a wide variety of game consumption}

\subsection{Zooarchaeological dietary studies}

The faunal record preserved at archaeological sites can give a very clear signal of the animals the inhabitants ate. Studies from Neanderthal sites outside Iberia suggest that Neanderthals hunted extensively (e.g., Lieberman, 1993; Lieberman and Shea, 1994), but focused almost exclusively on large game (e.g., Stiner and Kuhn, 1992; Stiner et al., 2000; Stiner, 2006), indicating a narrow diet. There is evidence that some Neanderthal groups in certain areas, such as the Caucasus (Adler et al., 2006; Adler and Bar-Oz, 2009) and France (Hardy and Moncel, 2011), may have had a wider diet that included plants and smaller animals, but this pattern is not very widespread.

The climatic conditions of Iberia from MIS 5 to MIS 3, together with the higher carnivore:ungulate ratio observed in several Middle Palaeolithic levels of sites from eastern Iberia compared to other European sites (Villaverde and Martínez Valle, 1992; Pérez Ripoll and Martínez Valle, 2001), and the fact that some large mammals, such as hippopotamus (Hippopotamus anphibius), elephant (Palaeoloxodon antiquus) or rhinoceros (Stephanorhinus hemitoechus), that went extinct in the rest of Europe before MIS 5 continued to exist later in Iberia, indicate that a different model is needed in Mediterranean Iberia to account for specific faunal changes than the one model offered for sites of the Euro-Siberian regions of similar chronology (Villaverde et al., 1998; Gamble, 1999).

Between the earliest occupations from the end of the Early Pleistocene to the last Neanderthal populations of the Late Pleistocene, there were several climatic phases that altered the position of the coastline in the central Mediterranean region of Iberia more than in the southeastern and southern areas (Colonese et al., 2011: 87). These changes, combined with the changes in humidity and dryness, affected the biotopes and distribution of animal biomass in various ways. During this period, there were several different animal communities that occupied this area. Some species were present during most of the sequence, particularly eurythermic taxa such as deer (Cervidae) and horse (Equidae). On the other hand, some temperate species from the last Interglacial period became rarer with time and eventually disappeared (Guérin and PatouMathis, 1996). The unique characteristics of the Mediterranean portion of the Iberian Peninsula excluded animals from cold conditions that were typical in more northerly areas (Delpech and Guérin, 1996; Barandiarán et al., 2012).

Various faunal studies from Middle Palaeolithic sites across the Iberian Peninsula indicate that Neanderthals obtained a wide variety of animals, scarcely different from the pattern observed in Iberian Early Upper Palaeolithic modern humans (Delpech and Grayson, 2007; Patou-Mathis, 2011). For example, studies in western and southwestern Iberia suggest that Neanderthals 
consumed predominantly medium and large-sized game, with scant evidence of small prey (i.e. Hockett and Haws, 2009). In the central Mediterranean area of Iberia, the pattern is broadly similar, with much of the zooarchaeological evidence suggesting that $\mathrm{Ne}$ anderthals were omnivores (Fischler, 2001) who obtained animal protein and fat mainly from medium- and large-sized herbivores, and hunted carnivores only sporadically. However, there is also evidence that they hunted small prey, quite often at some sites (Blasco and Fernández Peris, 2009; Brown et al., 2011), though at a lower frequency than is seen in the Upper Palaeolithic (Fa et al., 2013). Furthermore, in several areas, including Andalusia, Gibraltar and perhaps Murcia, Neanderthals used marine resources. In general, faunal patterns define the existence of complex resource management strategies by Neanderthals (e.g., Montes Bernárdez, 1988; Villaverde et al., 1996; Aura et al., 2002; Barroso et al., 2006a,b; Blasco, 2008; Sanchis and Fernández Peris, 2008; Stringer et al., 2008; Martínez Valle, 2009; Colonese et al., 2011; Cortés-Sánchez et al., 2011; Sanchis, 2012; Walker et al., 2012; Blasco and Fernández Peris, 2012a,b).

\subsection{The central area of the Mediterranean Iberian region}

Although there are many Middle Palaeolithic sites in the central Mediterranean region of Iberia, there is limited faunal information. Three cave sites with good stratigraphy, Cova del Bolomor (Tavernes de Valldigna, Valencia), Cova Negra (Xàtiva, Valencia) and Cova Beneito (Muro d'Alcoi, Alicante), provide the main archaeozoological and taphonomic evidence. Subsistence activities of Neanderthal groups, including their use of the environment and consumption of fauna, have been inferred from these studies. Two other sites in the region, Abric del Salt and Abric del Pastor (Alcoi, Alicante), have good chronostratigraphical and occupational information, but no complete zooarchaeological analysis has yet been completed (Sarrión, 1990; Galván et al., 2001; Marrero et al., 2011). A few other sites also have some faunal data, including Cova de Dalt del Tossal de la Font (Vilafamés, Castellón) (Olària et al., 20042005; Saladié et al., 2010), and Abrigo de la Quebrada (Chelva, Valencia) for the MIS 3 levels (Eixea et al., 2013; Sanchis et al., 2013).

The data from zooarchaeological studies of the Valencian region can be separated conveniently into four principal phases: the Middle Pleistocene (MIS 9-6), the early Late Pleistocene (MIS 5e), the middle Late Pleistocene (MIS 5d-4), and the later Late Pleistocene (MIS 3).

\subsubsection{The Middle Pleistocene (MIS 9-6)}

This period is represented by most of the sequence at Cova del Bolomor (levels XVII-VIII), and includes two harsher climatic periods (MIS 9/8 and 6) as well as a more clement one (MIS 7) (Fernández Peris, 2007). Several studies have provided zooarchaeological and taphonomic data about the macrofauna (Blasco et al., 2008, 2013; Blasco and Fernández Peris, 2009, 2010, 2012a), micro-mammals (Guillem, 2000) and most of the lagomorphs (Lagomorpha) (Sanchis and Fernández Peris, 2008, 2011; Sanchis, 2012). The common feature observed in all assemblages of the Middle Pleistocene levels is the great diversity of species: 12 taxa in level XI and XVIIc, 13 in level XII, and 16 in level XVIIa. Among them, rabbit (Oryctolagus cuniculus) is the most common animal both according to \%NISP and MNI, with red deer (Cervus elaphus) and horse (Equus feruus) the next most common species. Fallow deer (Dama dama) and tahr (Hemitragus sp.) also appear constantly in the Middle Pleistocene levels, albeit with frequency values under 5\%. Mega-herbivores such as elephant and rhinoceros are rare, as are aurochs (Bos primigenius) and carnivores (Blasco et al., 2008). Most species are represented by adult individuals. Bones from medium-sized and large species are highly fragmented, while bones from small species are not, suggesting differential transport of these size classes, with selection of some parts in the case of larger taxa and transport of the entire carcass for smaller species. Cut-marks and percussion marks indicative of marrow processing are present on 12-13\% (levels XII and XVIIa) of the remains, indicating that most of the fauna, including small prey such as birds and lagomorphs, was brought to the site by humans as food. Tooth marks and other evidence of carnivore intervention, for example by foxes (Vulpes sp.) and larger canids, are rare. Most of the fauna came from open valley and middle-mountain habitats, though some imply localities of high relief and others an aquatic source.

The human occupations corresponding to the Middle Pleistocene levels were probably of varying intensity, with periods of sporadic occupation interspersed with carnivore-dominated assemblages (Blasco et al., 2008). In the periods of more intense human occupation, there is very little evidence of any carnivore activity (Blasco and Férnandez Peris, 2010). Even among the small prey (birds, lagomorphs) there is evidence for human and nonhuman occupation of the cave. Some of the bones of the smaller game show evidence of digestion, or carnivore tooth- or beakmarks. However, other bones, including those from ducks (Aythia sp.) and lagomorphs, have cut-marks and human tooth-marks, clearly indicating that Neanderthals were consuming (or at least gnawing) these foods (Sanchis and Fernández Peris, 2008, 2011; Blasco and Fernández Peris, 2009, 2012a; Sanchis, 2012). Blasco and Fernández Peris (2012a) argue that this consumption of lagomorphs and other small game indicates that a widening of the diet did not occur only in modern human populations, but had already appeared in Neanderthal groups.

It is difficult to establish the way the humans from this period consumed their prey, since the remains are not burned, and often the anthropogenic marks appear together with modifications by other carnivores. For at least one level (XVIIc), the appearance of biting and scraping marks, consistent with scraping the bone (instead of filleting), as well as the lack of evidence for burning, suggest that meat was consumed raw (Sanchis and Fernández Peris, 2008).

\subsubsection{The early Late Pleistocene (MIS 5e)}

The later levels in the Cova del Bolomor sequence (VII to I) represent the temperate phases of the Last Interglacial (Fernández Peris, 2007; Fernández Peris et al., 2008). Of these, level IV has a large assemblage that includes 30 species, which represents an increase over the lower levels (Blasco, 2008; Blasco and Fernández Peris, 2012b). According to \%NISP and MNI, there is a preponderance of rabbit and red deer. The Mediterranean tortoise (Testudo hermanni) is also common, as has been noted at other sites from this period (Morales and Sanchis, 2009). Other species show changes compared to the earlier periods: reduction in the coldpreferring horse species, increase in aurochs, and appearance of forest taxa such as wild boar (Sus scrofa). Tahr and fallow deer are present at consistently low percentages, and all other species appear only in very low frequencies. Carnivores are represented by five species, where the wolf (Canis lupus), fox (Vulpes vulpes), lion (Panthera leo) and lynx (Lynx pardinus) predominate over the bears (Ursidae) (Blasco and Fernández Peris, 2012b).

Across all larger taxa, most of the specimens are of adults and are highly fragmented, consistent with human modification of fresh bone. Anthropogenic modifications such as cut-marks (7\%), percussion fractures, bite-marks and burning are common. Cutmarks appear on ungulate bones, as well as on carnivores and small game, and are most abundant on red deer and rabbit. Intentional fractures also appear on several taxa (red deer, tahr, fallow deer, wild boar and tortoise). Evidence for burning appears 
on $62 \%$ of the remains, especially on long bones. Carnivore damage is rare, and appears as bite-marks or gnaw-marks and digestion marks, all of which are assigned to the action of small canids, probably foxes. In cases when human and carnivore marks appear on the same bones, the marks indicate that humans had first access and that carnivores scavenged from their scraps. In the case of the Mediterranean tortoise, butchering, cooking, and human consumption processes have been described (Blasco, 2008).

Small game from this general period also suggests primary human accumulation (levels IV and Ia), with only one level (VIIc) showing evidence of primary carnivore accumulation. As with the larger game, the small game shows cut-marks, percussion marks, and burning, though less frequently than in later Upper Palaeolithic assemblages. Interestingly, there appears to have been differential processing of the fore and hind limbs of lagomorphs during this period. The forelimbs show evidence of burning consistent with roasting, while the hind limbs rarely have burning marks, and instead are fractured for marrow extraction (Sanchis et al., 2011). The inclusion of lagomorphs in Neanderthal diet could have been influenced by habitat characteristics as well as by the function and duration of the human occupations (Sanchis, 2012).

These results indicate that, in Level IV, Neanderthals actively occupied the site and introduced almost all of the taxa present, showing preference for the animals that were most abundant in the landscape. From those species larger than $\sim 20 \mathrm{~kg}$, they chose to transport only the parts with highest nutritional value to the cave, while smaller animals were transported whole and processed in the cave. The Neanderthals in this period show generalist behaviour based on the exploitation of a wide variety of game, which is among the earliest evidence for dietary diversification (Blasco and Fernández Peris, 2012b).

\subsubsection{The middle Late Pleistocene (MIS 5d-4)}

Assemblages from two caves, Cova Negra and Cova de Dalt del Tossal de la Font, represent this period. In Cova Negra, levels XIV-V correspond to two cold, harsh periods (MIS 5b-d and 4), separated by a temperate phase (MIS 5a) (Villaverde, 1984, 2006). At Cova de Dalt del Tossal de la Font, several levels have been assigned to MIS 5/4 (Saladié et al., 2010).

Early studies at Cova Negra indicated a large number of carnivores, as well as red deer, horse, and rabbit (Pérez Ripoll, 1977). The analysis of more recently excavated material presents a more nuanced interpretation (Martínez Valle, 2009). Megafauna dominates the assemblage, with several species of herbivores and carnivores found throughout the sequence, as well as a few smaller prey species such as lagomorphs and the hedgehog (Erinaceus europaeus). Furthermore, more than 40 species of birds have also been identified (Martínez Valle, 2009), and as many of micromammals (Guillem, 2000). The Mediterranean tortoise appears also quite frequently throughout the whole sequence (Morales and Sanchis, 2009). The most abundant remains are from adult red deer, which are mainly of anthropogenic origin as indicated by percussion marks and cut-marks. Horses are the next most common species, but their frequency diminishes through time. Horse bones show anthropogenic modification in some levels (VI and V) and carnivore damage in others (IX and VIII). Several other species also have evidence of cut-marks and percussion marks in various levels, including aurochs (level V) and rhinoceros (level XII). However, these species, along with the tahr, are generally rare in the assemblage. Coprolites and some of the carnivore damage indicate the presence of hyaena (Hyaenidae) in the lower levels, while much of the small game was likely accumulated by birds of prey (Sanchis, 2000, 2012; Martínez Valle, 2009). All this suggests a higher development of forested environments during the lower part of the sequence, while open areas with some trees characterize the middle part of the sequence (Martínez Valle, 2009). In addition, the high frequency of carnivore bones suggests occasional abandonment of the site by humans.

The faunal assemblages from Cova de Dalt del Tossal de la Font have a slightly different profile from those at Cova Negra. There is a predominance of herbivores, with cervids being the most common, but a relatively high proportion of equids (possibly Equus hydruntinus), bovids and suids. The most abundant carnivores are small and medium felids. The most common herbivore body parts are those with low food index values (metapodials, basipodials and phalanges). Cut-marks and tooth-marks are found on some red deer bones, but carnivores seem to have been responsible for most of the accumulation. Small game, such as lagomorphs and tortoises, was also predominantly carnivore accumulated (Saladié et al., 2010).

\subsubsection{The later Late Pleistocene (MIS 3)}

The final stage of Neanderthal occupation in this region occurred in MIS 3. Several sites have layers dating from this period, including the upper levels of Cova Negra (IV-I) (Villaverde, 1984, 2006), the entire Mousterian sequence of Cova Beneito (XII-X) (Iturbe et al., 1993; Domènech, 2001), and level IV of the recently excavated Abrigo de la Quebrada (Villaverde et al., 2008; Eixea et al., 2013).

A progressive decrease of cervids and horse is observed at the upper levels of Cova Negra, together with a considerable increase of caprinae (mainly tahr, but also Spanish ibex - Capra pyrenaica). Most of the caprinae remains are from juveniles and old individuals, and are predominantly represented by skull fragments and marginal limb parts. This assemblage is due to carnivore activity; only at level IIIb there is a mixed carnivore-anthropogenic signal. The deposit of cervid remains is also associated to carnivore activity, and most of them are from old and juvenile specimens. Horse remains indicate both carnivore and human activity, depending on the level. The few rhinoceros remains are carnivore accumulated (level IIIa). Although the most abundant signs on lagomorph and bird bones correspond to birds of prey, there are some cut-marks and tooth marks caused by Neanderthals (Martínez Valle, 2009). Eight species of carnivores are present at these upper levels, mostly wolf and dhole (Cuon sp.).

At Cova Beneito, Spanish ibex is the most common species (when lagomorphs are excluded), but its frequency varies from $65 \%$ in the lower levels (XII, XI) to $45-50 \%$ in the upper ones (X). Its decrease is associated with an increase in the percentages of red deer and horse. In the lower part of level X, Spanish ibex and red deer represent $80 \%$ of the identified skeletal remains, while in the upper part, Spanish ibex, red deer and horse add up to $90 \%$ of the total remains. There is low presence of other taxa such as chamois (Rupicapra rupicapra), aurochs, rhinoceros and wild boar. Carnivore remains are also very scarce. Lagomorphs and birds are more common in the lower levels than in the upper ones (Martínez Valle and Iturbe, 1993). Both carnivores and humans were responsible for parts of the accumulation. Spanish ibex was accumulated predominantly by carnivores in level XI and the lower part of level $\mathrm{X}$, but mostly accumulated by humans in level XII and the upper part of X. The red deer was accumulated by humans, except for level XII where both humans and carnivores contributed to the assemblage. Horse remains were also processed by Neanderthals. Some cut-marks are observed on wild boar and chamois bones, but the origin of large bovids and rhinoceros is unknown. Carnivore bones show no anthropogenic marks, and it is possible that hyaenas occupied the lower levels of the cavity as a den. Lagomorphs and birds were predominantly accumulated by raptors, with rare evidence of human action on them. The fauna from Cova Beneito is 


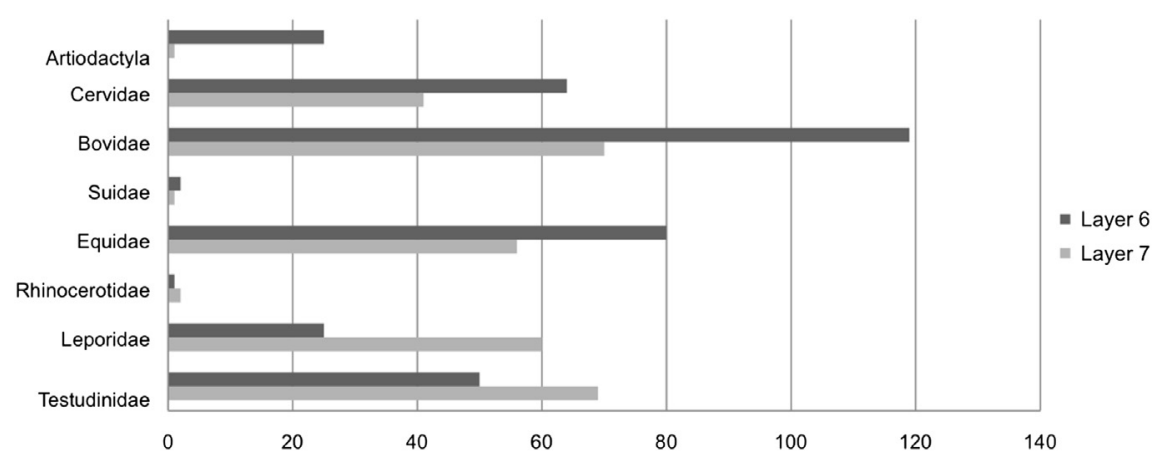

Fig. 3. Represented animal species (NISP) from level IV of Abrigo de la Quebrada.

associated with a forested landscape with some humidity during most part of the sequence (XII, XI and beginning of X), while during the last moments (level $\mathrm{X}$ ) there is a decrease in humidity and the development of more open areas.

The data from Cova Negra and Cova Beneito suggest the use of a non-specialised hunting strategy by Neanderthals, based on the capture of cervids, horse and some caprinae. This hunting strategy is associated with short, temporally separated occupations of the caves (high territorial mobility pattern). When humans were not using caves, hyaenas (lower levels of Cova Negra and Cova Beneito) or canids (upper levels of Cova Negra and several levels of Cova Beneito) occupied the sites and were the primary accumulators of herbivore remains. Throughout the sequences, birds of prey also occupied these sites or adjacent areas, producing most of the lagomorph and bird bone accumulations (Villaverde and Martínez Valle, 1992; Martínez Valle, 2009; Sanchis, 2012).

The above-mentioned data for this period can be compared to the new results from the faunal assemblages of level IV (MIS 3 ) of Abrigo de la Quebrada (Sanchis et al., 2013). Spanish ibex and horse are more abundant than red deer (Fig. 3). The caprinae remains are predominantly adults, with an equal representation of all anatomical parts. Similarly, Spanish ibex and red deer are predominantly adult specimens with equal representation of all body parts, suggesting these species were transported to the site as complete carcasses. This contrasts with equids, which are represented mostly by teeth, suggesting that Neanderthals selected only their heads. Other herbivores (rhinoceros and wild boar) and carnivores (fox) are rare. Small game is not abundant compared to large ungulates, and the primary accumulator is unknown. One tortoise shell plate has cutmarks on the inner side, suggesting that Neanderthals processed or consumed these reptiles (Fig. 4). No carnivore marks have been found. The taxa found at this site and the distribution of anthropogenic marks suggest a diversified model of prey acquisition focused on middle- and large-sized ungulates from an environment characterized by areas of both high relief and valleys. These results are based on the analysis of two layers of level IV. The remaining material from other layers and levels is currently under study, which will provide information on how the occupation of this site changed through time. New work suggests that the lower levels may have a different model of shelter occupation (Eixea et al., 2013).

\subsection{Murcia}

There are many Middle Palaeolithic sites in the Murcia region (Montes Bernárdez, 1992; Zilhão and Villaverde, 2008; Walker et al., 2012), but the zooarchaeological data as yet are not as comprehensive as for the central Mediterranean region, so we present only a general overview.

There are important Mousterian sites along the coast, including Cueva de los Aviones (Cartagena), Sima de las Palomas del Cabezo Gordo (Torre Pacheco), and Cueva Perneras (Lorca). At these sites there are many mammals and occasionally marine molluscs from
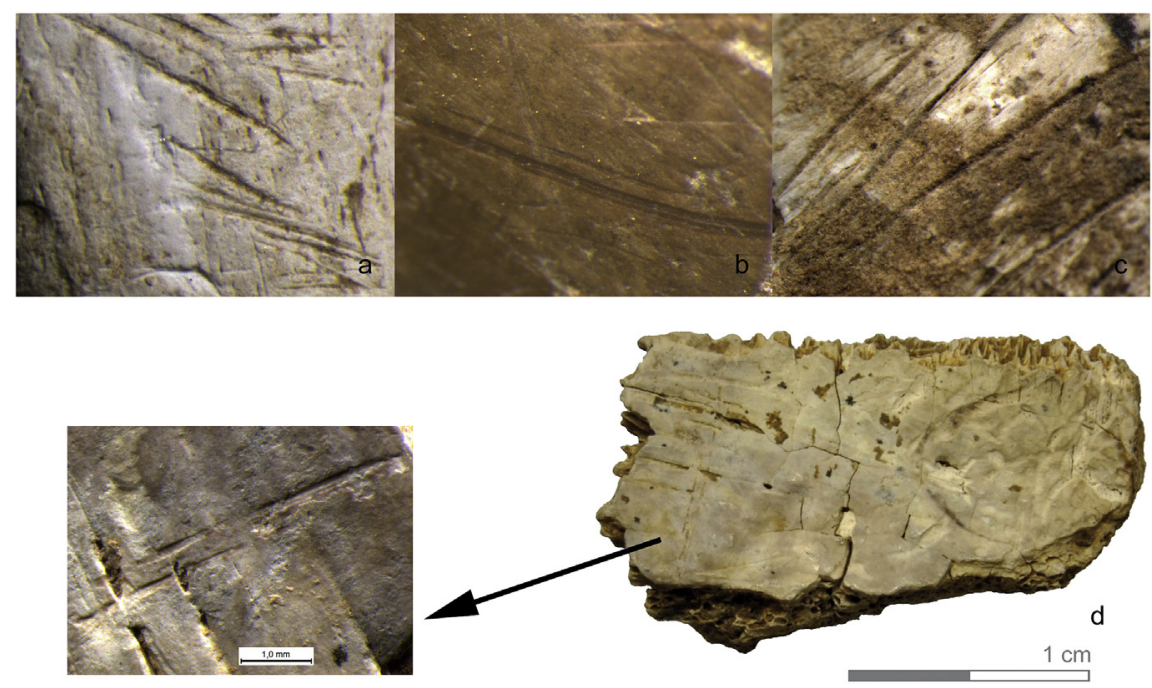

Fig. 4. Abrigo de la Quebrada (level IV). Several remains with cut-marks (a-c). Tortoise plaquette with cut-marks on inner side (d). 
rocky habitats. Mediterranean molluscs Monodonta turbinata, Patella ferruginosa and Mytilus edulis were present at Cueva de los Aviones, which today is on the shore but may have been $1-7 \mathrm{~km}$ away from the coast during the Pleistocene; the abundant mollusc remains are evidence of dietary and possibly symbolic use (Montes Bernárdez, 1988, 1989, 1992; Zilhão et al., 2010). These marine resources may have been an important complement of Neanderthal diet at Cueva de los Aviones though terrestrial mammals and reptiles are also represented.

The situation is very different at the Sima de las Palomas del Cabezo Gordo, which is only $4 \mathrm{~km}$ from the large Mediterranean lagoon called the Mar Menor, and can have been hardly more than $10 \mathrm{~km}$ from the sea even at times of maximal marine regression. The site has important excavated Neanderthal articulated skeletons and Mousterian tools dating from ca. $50 \mathrm{ka}$. Despite its proximity to the sea, fewer than half-a-dozen fragments of marine molluscs (Pecten maximus and Cerastoderma edule) have been found, while terrestrial fauna is abundant, and includes leopard (Panthera pardus), hyaena, lynx, wild cat (Felis silvestris), wolf, fox, badger (Meles sp.), porcupine (Hystrix brachyura), hippopotamus, rhinoceros, horse, wild ass (Equus africanus), aurochs, Spanish ibex, red deer, fallow deer, rabbit, hedgehog, bat (Chiroptera), tortoise and lizard (Lacertilia) (Walker et al., 2012). Some leopard, hyaena and horse remains show signs of having been burnt, which implies that humans had killed them. A hippopotamus incisor has an artificial groove, perhaps for suspension.

There are several cave sites in the inland part of the Murcian region with Late Pleistocene Mousterian assemblages, including
Abrigo Grande del Cabezo Negro and Cueva Antón, as well as several open-air sites. These sites preserve different tool technologies, but all are associated with a typical faunal assemblage from this stage of the Late Pleistocene that includes red deer, Spanish ibex, horse and rabbit, as well as tortoise and hyaena (Montes Bernárdez, 1992). At Cueva Antón, the most abundant faunal remains are lagomorphs, mostly in levels I and II (Sanchis, 2012). Based on beak-marks, age-profiles, and degree of fragmentation, these rabbits were accumulated by raptors (levels IIk-1 and Ilu), and are not associated with the other faunal remains (red deer) that appear almost exclusively in level III. The biggest faunal remains from level III have anthropogenic modifications, including cutmarks and percussion fractures, and many are associated with combustion structures. However, there are very few tools, and the low numbers of processed bones suggest very short stays and/or very specific activities (Zilhão and Villaverde, 2008; Zilhão et al., 2010).

In summary, for both the central and southeastern Mediterranean regions of Iberia, the patterns among the fauna suggest that Neanderthals were making use of the foods that were available locally, depending on the current environmental conditions and on the location of the sites (latitude, altitude, sea proximity). The zooarchaeological studies done in these sites show that Neanderthal diet was based on medium and large-sized animals, and only some sites like Cova del Bolomor show significant capture of small game (Table 1). Overall, these results do not differ greatly from those observed in other southern regions of the Iberian Peninsula (Haws et al., 2011).

Table 1

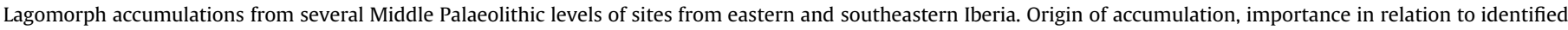

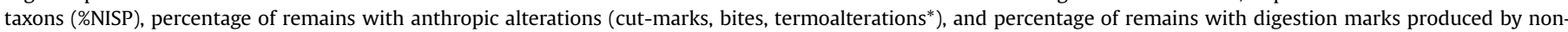
human predators, are represented.

\begin{tabular}{|c|c|c|c|c|c|c|}
\hline Archaeological site & MIS & Level & Origin of the accumulation & \%NISP & $\%$ Anthropic & \% Digested \\
\hline \multirow[t]{6}{*}{ Cova del Bolomor (Sanchis, 2012) } & 9 & XVIIc & Mixed (bird of prey-anthropic) & 58.7 & 3.7 & 7.2 \\
\hline & 9 & XVIIa & Bird of prey & 76.9 & & 12.1 \\
\hline & 8 & XV & Mixed (bird of prey-anthropic) & 88.2 & 0.5 & 9.4 \\
\hline & 7 & XIIIC & Carnivore & 88.9 & & 32.5 \\
\hline & $5 e$ & IV & Mixed (carnivore-anthropic) & 37.2 & $3.8 / 8.4^{*}$ & 2.1 \\
\hline & $5 e$ & Ia & Anthropic & 14.1 & $7.6 / 7.6^{*}$ & \\
\hline \multirow[t]{5}{*}{ Cova del Bolomor (Blasco, 2011) } & 9 & XVIIc & Mixed (bird of prey-carnivore-anthropic) & 62.6 & 6.7 & 2.9 \\
\hline & 9 & XVIIa & Mixed (bird of prey-carnivore-anthropic) & 61.6 & 3.9 & 10.5 \\
\hline & 6 & XII & Anthropic & 6.5 & 4.5 & \\
\hline & 6 & $\mathrm{XI}$ & Anthropic & 25.1 & $14.9 / 69.1^{*}$ & \\
\hline & $5 e$ & IV & Anthropic & 27.5 & $18 / 60^{*}$ & 0.2 \\
\hline \multirow{13}{*}{ Cova Negra (Martínez Valle, 2009) } & $5 a$ & XII & Bird of prey & 94.3 & & 16.5 \\
\hline & 4 & XIb & Bird of prey & 96.5 & & 0.8 \\
\hline & 4 & XIa & Bird of prey & 98.1 & & 2.6 \\
\hline & 4 & $\mathrm{X}$ & Bird of prey & 100 & & 1.8 \\
\hline & 4 & IX & Bird of prey & 97.5 & & 4.2 \\
\hline & 4 & VIII-IX & Bird of prey & 94.4 & & 1.3 \\
\hline & 4 & VII & Bird of prey & 95.1 & & 1.7 \\
\hline & 4 & VI & Bird of prey & 61.8 & & 9.3 \\
\hline & 4 & $\mathrm{~V}$ & Bird of prey & 42.3 & & 14.6 \\
\hline & 3 & IV & Mixed (bird of prey-anthropic) & 68.3 & 0.8 & 7.3 \\
\hline & 3 & IIIb & Mixed (bird of prey-anthropic) & 61.6 & 1.2 & 12.7 \\
\hline & 3 & IIIa & Mixed (bird of prey-anthropic) & 69.1 & 1.1 & 9.5 \\
\hline & 3 & II & Mixed (bird of prey-anthropic) & 45.8 & 0.7 & 9.9 \\
\hline \multirow[t]{2}{*}{ Cova de Dalt del Tossal de la Font (Saladié et al., 2010) } & 5,4 & Ic, $\mathrm{f}$ & Carnivore & 42.9 & & \\
\hline & 5,4 & IIa & Carnivore & 2.9 & & \\
\hline \multirow[t]{4}{*}{ Cova Beneito (Martínez Valle, 2009) } & 3 & D4 & Mixed (bird of prey-anthropic) & 87.1 & 0.1 & 3.7 \\
\hline & 3 & D3 & Bird of prey & 60.9 & & 9.4 \\
\hline & 3 & D2 & Mixed (bird of prey-anthropic) & 64.1 & 1.8 & 6.5 \\
\hline & 3 & D1 & Mixed (bird of prey-anthropic) & 55.4 & 1.8 & 15 \\
\hline \multirow{2}{*}{ Abrigo de la Quebrada (Sanchis et al., 2013) } & 3 & IV (c7) & Unknown & 6.8 & & \\
\hline & 3 & IV (c6) & Unknown & 19.9 & & \\
\hline \multirow[t]{2}{*}{ Cueva Antón (Sanchis, 2012) } & 3 & IIk-1 & Bird of prey & 100 & & 12.8 \\
\hline & 3 & Ilu & Bird of prey & 100 & & 12 \\
\hline
\end{tabular}




\section{Stable isotopes: dietary rigidness?}

\subsection{Stable isotopes and palaeodietary reconstructions}

Carbon and nitrogen stable isotope analysis are a commonly used method for the reconstruction of past human and animal diets. This technique is based on the principle that the isotopic composition of the food eaten by both animals and humans is recorded on their body tissues after a predictable isotope fractionation (Schoeller, 1999, and see reviews by; Ambrose, 1993; Katzenberg, 2000; Sealy, 2001; Lee-Thorp, 2008).

The relative abundance of the stable carbon isotopes ${ }^{13} \mathrm{C}$ and ${ }^{12} \mathrm{C}$ $\left(\delta^{13} \mathrm{C}\right)$ clearly distinguishes the consumption of terrestrial $\left({ }^{13} \mathrm{C}\right.$ depleted) and marine foods $\left({ }^{13} \mathrm{C}\right.$ enriched) (Chisholm et al., 1982). It helps as well to differentiate between the dietary input from $C_{3}$ plants or animals that consumed them $\left({ }^{13} \mathrm{C}\right.$ depleted) and from $\mathrm{C}_{4}$ resources $\left({ }^{13} \mathrm{C}\right.$ enriched) (Van der Merwe and Vogel, 1978). However, since no edible $\mathrm{C}_{4}$ plants are known in Europe during the Neanderthal era (Cerling, 1999; Sage et al., 1999), the main use of carbon isotopes is for estimating the consumption of marine proteins. In an ecosystem devoid of $\mathrm{C}_{4}$ plants such as the European one, a $\delta^{13} \mathrm{C}$ value around $-20 \%$ would indicate a diet of entirely terrestrial foods, while a value about $-12 \%$ would indicate that almost all of the ingested protein was of marine origin.

The nitrogen stable isotope ratio of ${ }^{15} \mathrm{~N}$ and ${ }^{14} \mathrm{~N}\left(\delta^{15} \mathrm{~N}\right)$ increases by $3-5 \%$ with each trophic level up the food chain, which means that the consumer has higher values than the consumed protein (De Niro and Epstein, 1981; Schoeninger and De Niro, 1984). This makes nitrogen stable isotopes useful for detecting the presence of high trophic level marine and freshwater fish in the diet (Schoeninger et al., 1983), as well as for distinguishing animal-rich diets from plant-rich diets (low values of $\delta^{15} \mathrm{~N}$ mean a higher consumption of plant foods, while high values mean higher meat consumption) (Minagawa and Wada, 1984).

Collagen from bones and teeth is the preferred substrate for carbon and nitrogen stable isotope analysis, because it provides accepted quality indicators of its isotope integrity and it is the only considerable nitrogen source from skeletal remains (De Niro, 1985; Van Klinken, 1999). Several characteristics of collagen must be considered when proceeding with dietary reconstruction. Although bone is renewed constantly, since collagen turnover is quite low and decreases significantly after the growth period, collagen stable isotope values reflect an average diet thought to represent at least 5-15 years of an individual's life prior to its death (Hedges et al., 2007). Also, collagen stable isotope ratios reflect the isotopic signals of the main dietary protein sources rather than that of diet as a whole, especially for nitrogen (Ambrose and Norr, 1993). Depending on dietary protein levels, carbon may be derived from other dietary macronutrients (sugars and fats) (Howland et al., 2003; Jim et al., 2006).

\subsection{Neanderthal dietary isotopic evidence}

Palaeodietary reconstructions carried out during the last two decades on Neanderthal specimens and associated fauna from between 120 and 30 ka have provided information about the diet of these Pleistocene humans. The first analysis on Neanderthals was done on Les Pradelles (France) (Fizet et al., 1995). Since then, about twenty other specimens have been analysed around the Eurasian continent (see review from Richards and Trinkaus, 2009). These analyses show a quite uniform Neanderthal dietary trophic ecology, regardless of geographic area and chronology. They place Neanderthals on the highest level of the food chain, and suggest that Neanderthals were top predators that obtained almost all of their dietary protein from animal resources, mainly medium and largesized herbivores from open-air areas (Lee-Thorp and Sponheimer,
2006). This interpretation is based on the comparison of their nitrogen isotopic signatures to that of contemporary animal bones, some of which come from the same sites and layers as the Neanderthal specimens (e.g., Richards et al., 2000, 2008; Bocherens et al., 2005), and others that come from faunal accumulations that provide ecological niche information (e.g., Iacumin et al., 2000; Richards and Hedges, 2003). In all of these comparisons Neanderthals have much higher nitrogen values than those from herbivores such as the horse, reindeer (Rangifer tarandus), red deer, Spanish ibex, chamois, steppe bison (Bison priscus) or aurochs, and are similar to or a bit higher than those of predators such as the wolf, hyena and lion. Though these analyses can't rule out plant consumption because of their methodological limitations, they may suggest that Neanderthals did not regularly consume plant protein. Furthermore, there is no isotopic evidence for any marine or freshwater protein consumption by Neanderthals.

This high level of animal protein indicated by the nitrogen isotopes is consistent only with constant and active sophisticated hunting (Richards, 2002; Richards and Schmitz, 2008) supported by developed speech skills as suggested by their genetics (Krause et al., 2007). These results suggest a rigid dietary pattern among Neanderthals that is specific to them as a species. This would mean that they could have been more vulnerable in case they competed for food resources during the Middle and Upper Palaeolithic transition with modern humans (Bocherens and Drucker, 2006), of which the isotopic evidence suggest a higher variability in the diet (Richards and Trinkaus, 2009). However, all of these interpretations are based on analyses carried out on Neanderthals from northern latitudes and cold environments. Only recently have some results from a more southern and temperate region, the central area of the Mediterranean coast of Iberia, begun to show a broader picture on Neanderthal isotopic values and their palaeodietary implications (Salazar-García, 2012).

\subsection{Isotopic evidence from central Mediterranean Iberia}

The Neanderthal carbon and nitrogen isotope ratio values from four human remains of Cova Negra and Abric del Salt, as well as their associated fauna, are an important contribution to the debate about Neanderthal dietary rigidity (Salazar-García, 2012). They begin to fill the empty void of isotopic studies on Neanderthals from southern Europe and other latitudes at which climatic conditions were milder and where more abundant edible plant foods existed. Part of the reason for the lack of information on these latitudes is that these same warmer climatic conditions have made it more difficult for collagen to be preserved.

The results from Cova Negra and Abric del Salt show for the first time that Neanderthals living in more temperate environments present similar values to those living in more cold environments. These stable isotope results describe a diet for these Eastern Iberia Neanderthals that is largely terrestrial and based on large and medium-sized herbivores. Its interpretation is compatible with the zooarchaeological studies at both sites, where all of the faunal remains are from terrestrial animals, as already discussed, showing that Neanderthals living in the less cold and arid regions of Europe are also top-level carnivores.

Although plant food resources were available to Neanderthals (seeds, acorns, wild berries, wild olives, etc.) in this region, it is not surprising that the isotope evidence from these southern European Neanderthals shows no trace of them as a major part of the diet, considering that when a lot of meat is eaten there is a low resolution detecting plant consumption. Therefore it is necessary to assess the plant consumption issue by studying phytolith and starch grain analysis on dental calculus from other Neanderthal specimens of the region. Still, so far the only direct evidence of 
long-term food consumption, carbon and nitrogen stable isotope analysis on bone collagen continue to show that Neanderthal dietary protein was dominated by animal protein.

\section{The role of plant foods}

\subsection{Evidence of Neanderthal plant consumption}

Relatively few studies have examined plant use by Neanderthals. Nutritional and energetic studies indicate that Neanderthals could not have survived solely on terrestrial game (Hockett, 2012), and plant foods would have provided at least some of the required nutrients and calories (Jones, 2009). Evidence for Neanderthal plant use comes from a variety of sources. Studies of Neanderthal tools from Eastern and Western European sites have shown that they were using several kinds of plants (Hardy et al., 2001; Hardy, 2004). Dental microwear studies suggest that Neanderthals from lower latitudes consumed a mixed diet including plants (El Zaatari et al., 2011). Macrobotanical analysis at the Middle Palaeolithic site of Kebara (Israel) identified the charred remains of seeds preserved in hearths and found evidence for use of legumes, acorns and pistachio nuts (Lev et al., 2005). Studies of plant microremains preserved in soils (Henry et al., 1996, 2004; Albert et al., 1999, 2000; Rosen, 2003) and dental calculus (Henry et al., 2011) from Near Eastern sites suggest that Neanderthals may have consumed a variety of plant foods such as date palms and grains. In cold northern European environments, the study of phytoliths and starch grains in dental calculus from Spy Cave (Belgium) indicated that grass seeds and underground storage organisms were part of Neanderthal diet (Henry et al., 2011).

In this context, information on plant microremains from the Western Mediterranean is almost compulsory. Though the environmental reconstructions of southeastern Iberia suggest abundant plant foods, relatively little is actually known about Neanderthal consumption of these foods. Palynology implies the existence of productive ecosystems during the Middle Pleistocene, but also indicates that southeastern Iberia may have had environments were plant foods were more important than in other regions. Forested landscapes of the Middle Pleistocene have been generally characterized as less suited for supporting the prey favoured by Neanderthals (Gaudzinski-Windheuser and Roebroeks, 2011). However, the forests present in southeastern Iberia would have been Mediterranean rather than dense coniferous forests. This zone, which was surrounded by extensive belts of intermediate habitat deciduous forest, would have provided a seasonal abundance of energyrich edible plant foods such as hazel (Corylus avellana), olive (Olea europaea), legumes (Fabaceae), acorns (Quercus spp.), walnut (Juglans spp.), pistachio (Pistacia spp.), grape (Vitis spp.), strawberry tree fruit (Arbutus unedo) and pine nuts (Pinus spp.). Furthermore, other studies have also indicated that plants were important parts of Neanderthal diets not only in southernmost parts such as at Gorham's Cave in Gibraltar (Barton et al., 1999), but even in northern parts of Spain (Hardy et al., 2012). Therefore, plant foods may have been especially important in Neanderthal diets in southeastern Iberian refugia.

\subsection{Direct evidence of plant use at Sima de las Palomas}

To investigate non-meat diet in this region, we collected dental calculus from Neanderthals at Sima de las Palomas, Murcia, and analysed the plant microfossils it contained. Excavations at Sima de las Palomas by Walker and colleagues have recovered Neanderthal remains including three articulated skeletons in anatomical connection, and apart from teeth in their alveoli there are another 60 separate isolated teeth (Walker et al., 2008, 2010, 2011a, 2011b, 2012).

In multiple studies, both modern and ancient dental calculus has been demonstrated to entrap food remains, such as starches and phytoliths (Armitage, 1975; Boyadjian et al., 2007; Henry and Piperno, 2008; Piperno and Dillehay, 2008). These food particles can provide information on plant matter that entered the mouth during life. Thus this approach can overcome some of the taphonomic biases that otherwise obscure the evidence of plant use.

We collected dental calculus from eleven Neanderthal teeth. The sampled teeth had a visible band of hard supragingival calculus situated on the tooth surface. Additionally, we studied the residues on seven Mousterian tools from the site. Each tool was sampled on both worked and unworked faces (the unworked or unused face is defined as the butt flake end while the used edge was defined as the retouched edge of the flake).

We also took a variety of control samples, including calculus from seven carnivore teeth and cotton storage material. The carnivores may have consumed plant matter, but these plants are unlikely to have been the same species eaten by Neanderthals, and would have been consumed only intermittently. We also processed sediments and took wash samples of randomly selected unworked stones as tests for contamination from the surrounding cave sediment.

Microfossils were photographed, described, and documented using the International Code for Starch Nomenclature (ICSN, 2011) and International code of phytolith nomenclature (Madella et al., 2005). Images of all microfossils are accessible on the Archaeological Microfossil Database of the Plant Foods and Hominin Dietary Ecology Research Group at the Max-Planck Institute for Evolutionary Anthropology. Microfossils were assigned to types based on their shared morphology. Some of the types may be unique to a single plant, but other types may all have originated from one plant. For example, three phytolith types (short-cell, bulliform and psilate) may all represent a single species of grass. Furthermore, many categories of plant food, which would have been regionally present, are likely to have few or no phytoliths or starches. These include lipid, sugar or inulin-rich plants, like olive, walnut, and pistachio. Where possible, the microfossil types were identified to plant part and taxonomic origin based on comparisons to a reference collection of over 1000 plants.

We recovered both phytoliths and starch grains, and observed more than nine microfossil types from the Neanderthal calculus (Tables 2 and 3). The microfossil counts from these remains are not high. The recovered microfossils indicate that the Neanderthals consumed a diversity of plant types, such as leafy matter indicated by polyhedral phytolith multi-cells, hard endosperm of seeds or nuts as well as grass seeds (Table 4, Fig. 5), and possibly

Table 2

Total microfossils in Neanderthal calculus, lithic tools, and controls.

\begin{tabular}{|c|c|c|c|c|c|c|c|}
\hline Type & Sample $=n$ & N. Starches & Av starches/sample & N. phytoliths & Av phytoliths/sample & Total microfossils & Av microfossil/sample \\
\hline Neanderthal calculus & 11 & 20 & 1.81 & 16 & 1.45 & 36 & 3.27 \\
\hline Carnivore calculus $^{\mathrm{a}}$ & 8 & 0 & 0 & 3 & 0.38 & 3 & 0.38 \\
\hline Mousterian tools: used surface & 7 & 12 & 1.71 & 11 & 1.57 & 24 & 3.42 \\
\hline Mousterian tools: unused surface $\mathrm{e}^{\mathrm{a}}$ & 7 & 12 & 1.71 & 13 & 1.86 & 25 & 3.57 \\
\hline Non-worked stone $\mathrm{a}^{\mathrm{a}}$ & 7 & 4 & 0.57 & 12 & 1.71 & 16 & 2.29 \\
\hline Storage cotton ${ }^{\mathrm{a}}$ & 1 & 0 & 0 & 0 & 0 & 0 & 0 \\
\hline
\end{tabular}

a Control samples. 
Table 3

Additional details on the type, provenience and material of samples.

\begin{tabular}{|c|c|c|c|}
\hline Descriptions & Type & Provenience & Material \\
\hline \multicolumn{4}{|l|}{ Lithic tools } \\
\hline SPT1 & Used & \multirow[t]{2}{*}{ Upper west cutting IA2 } & \multirow{2}{*}{$\begin{array}{l}\text { Flint with } \\
\text { patina }\end{array}$} \\
\hline SPT1 & Unused & & \\
\hline SPT2 & Used & \multirow[t]{2}{*}{ Upper north cutting IA } & Flint with \\
\hline SPT2 & Unused & & $\begin{array}{l}\text { patina and } \\
\text { cortex }\end{array}$ \\
\hline SPT3 & Used & \multirow[t]{2}{*}{ Upper west cutting IAe $+\mathrm{h}$} & \multirow[t]{2}{*}{ Quartzite } \\
\hline SPT3 & Unused & & \\
\hline SPT4 & Used & \multirow[t]{2}{*}{ Upper north cutting IAd } & \multirow[t]{2}{*}{ Quartzite } \\
\hline SPT4 & Unused & & \\
\hline SPT5 & Used & SP07 S second westward & Massive \\
\hline SPT5 & Unused & extension EWE2/2e/0001 & quartz \\
\hline SPT6 & Used & \multirow[t]{2}{*}{ Upper westwards cutting/Iab } & \multirow{2}{*}{$\begin{array}{l}\text { Flint with } \\
\text { cortex }\end{array}$} \\
\hline SPT6 & Unused & & \\
\hline SPT7 & Used & \multirow[t]{3}{*}{ PLAT 900H/0001-7 } & \multirow{3}{*}{$\begin{array}{l}\text { Crystalline } \\
\text { quartz }\end{array}$} \\
\hline SPT7 & Unused & & \\
\hline Teeth & & & \\
\hline SP50 & Lower LM $^{3}$ & Hillside rubble & $\mathrm{n} / \mathrm{a}$ \\
\hline SP53 & Upper $\mathrm{LP}^{4}$ & Upper Cutting level 2c & $\mathrm{n} / \mathrm{a}$ \\
\hline SP58 & Lower $\mathrm{RM}^{3}$ & Upper Cutting level $2 \mathrm{~d}$ & $\mathrm{n} / \mathrm{a}$ \\
\hline SP60 & Upper $\mathrm{RP}^{3}$ & Upper Cutting level $2 \mathrm{f}$ & $\mathrm{n} / \mathrm{a}$ \\
\hline SP60 & Upper $\mathrm{RP}^{3}$ & Upper Cutting level $2 f$ & $\mathrm{n} / \mathrm{a}$ \\
\hline SP68 & Upper $\mathrm{RP}^{3} \& \mathrm{P}^{4}$ & Upper Cutting level IA & $\mathrm{n} / \mathrm{a}$ \\
\hline SP74 & Upper LC & Upper Cutting level IAi & $\mathrm{n} / \mathrm{a}$ \\
\hline SP78 & Lower $\mathrm{LP}^{4}$ & Upper Cutting level 2c & $\mathrm{n} / \mathrm{a}$ \\
\hline SP88 & Lower LDM $^{2}$ & Upper Cutting level $2 \mathrm{~g}$ & $\mathrm{n} / \mathrm{a}$ \\
\hline SP100a & Lower $\mathrm{LM}^{1} / \mathrm{M}^{2}$ & Upper cutting $2 \mathrm{~K}$ & $\mathrm{n} / \mathrm{a}$ \\
\hline SP100b & Lower $\mathrm{LM}^{1} / \mathrm{M}^{2}$ & Upper cutting $2 \mathrm{~K}$ & $\mathrm{n} / \mathrm{a}$ \\
\hline
\end{tabular}

underground storage organs (Fig. 6). The starch grains found in calculus largely overlap with the types recovered on the stone tools (Table 4).

Stone tools are more prone to environmental contamination as they may lack a protective matrix of calculus but many studies have suggested that the risk is predominantly post-excavation (Loy and Barton, 2005; Williamson, 2005). Experimental studies have indicated that microfossils occur on tool surfaces that are unused (Fullagar et al., 2006). The wash samples of randomly selected stones show phytoliths and some starch contamination, however these stones were selected from a unit balk that was exposed to atmospheric airborne microfossils for an extended period of time. Sediment samples that were from unexposed areas have few microfossils, suggesting low contamination from the burial matrix. Carnivore calculus showed one starch and several grass phytoliths, which may have resulted from rare incidences of plant consumption The low numbers do not support contamination from cave sediment.

All of these results are the first direct evidence of Palaeolithic plant consumption in Mediterranean Iberia. The recovered microfossils suggest that Neanderthals consumed some diversity of plant species. And, although we cannot yet fully model the relative consumption of plant foods versus other foods, our results also support other studies that suggest that plants may have been regularly consumed and an important source of nutrients for $\mathrm{Ne}-$ anderthals, if not a major source of calories. Previous studies have noted that several of the Sima de las Palomas individuals have dental caries (Walker et al., 2011c). Dental caries are rare in $\mathrm{Ne}-$ anderthals. In modern human populations, the frequency of caries

Table 4

Starch types from Sima de las Palomas Neanderthal calculus and Mousterian tools.

\begin{tabular}{|c|c|c|c|c|c|c|c|c|c|c|c|c|c|c|c|}
\hline \multirow[t]{2}{*}{ Descriptions } & \multirow[t]{2}{*}{ Type } & \multicolumn{9}{|c|}{ Starch types } & \multicolumn{4}{|c|}{ Phytolith morphotypes } & \multirow[t]{2}{*}{ Total } \\
\hline & & 1 & 2 & 3 & 4 & 5 & 6 & 7 & 8 & $\mathrm{D} / \mathrm{I}$ & $\begin{array}{l}\text { Polyhedral } \\
\text { multi-cell }\end{array}$ & Short-cell & Bulliform & Psilate & \\
\hline \multicolumn{16}{|l|}{ Lithic tools } \\
\hline SPT1 & Used & & 2 & & 1 & & & & & 1 & & 1 & & & 5 \\
\hline SPT1 & Unused & & 1 & & & 1 & & & & & & & & & 2 \\
\hline SPT2 & Used & & & 2 & & & & & & & & & & & 2 \\
\hline SPT2 & Unused & & 1 & & & & & & & & & & & & 1 \\
\hline SPT3 & Used & & & & & & & & & & & & & 1 & 1 \\
\hline SPT3 & Unused & & & 1 & & & & & & & & & 1 & & 2 \\
\hline SPT4 & Used & & & & & 1 & & & & 1 & & & & & 2 \\
\hline SPT4 & Unused & & & & & 1 & & & & & & & & & 1 \\
\hline SPT5 & Used & & 2 & & & & & 1 & & & & & & & 3 \\
\hline SPT5 & Unused & & 1 & & & & & & & & & & & & 1 \\
\hline SPT6 & Used & & & & & & 1 & & & & & & & & 1 \\
\hline SPT6 & Unused & & 1 & & & 2 & 1 & & & & & & & & 4 \\
\hline SPT7 & Used & & & & & & & & & & & 10 & & 1 & 14 \\
\hline SPT7 & Unused & & 1 & & 1 & & & & & & 10 & & 1 & & 14 \\
\hline \multicolumn{16}{|l|}{ Teeth } \\
\hline SP50 & Lower $\mathrm{LM}^{3}$ & & & & & & & & & & & & & & 0 \\
\hline SP53 & Upper $\mathrm{LP}^{4}$ & & & & & & & & & & & 3 & & & 3 \\
\hline SP58 & Lower $\mathrm{RM}^{3}$ & & & & & & & & & 1 & & 3 & & 1 & 5 \\
\hline SP60 & Upper $\mathrm{RP}^{3}$ & & & & & & & & & & & & & 0 & \\
\hline SP60 & Upper $\mathrm{RP}^{3}$ & & & & & & & & & 1 & & 2 & & & 3 \\
\hline SP68 & Upper $\mathrm{RP}^{3} \& \mathrm{P}^{4}$ & & & & & & & & & & 1 & 1 & 1 & & 3 \\
\hline SP74 & Upper LC & & & 1 & 1 & & 1 & & 2 & 3 & & & & & 8 \\
\hline SP78 & Lower $\mathrm{LP}^{4}$ & 1 & & & & & & & 1 & 2 & 1 & & & & 5 \\
\hline SP88 & Lower LDM ${ }^{2}$ & & & & & & & & 1 & & & & 2 & & 3 \\
\hline SP100a & Lower $\mathrm{LM}^{1} / \mathrm{M}^{2}$ & & & & & & & & & & 3 & & & & 3 \\
\hline SP100b & Lower $\mathrm{LM}^{1} / \mathrm{M}^{2}$ & 1 & & 1 & & & & & & 3 & & & & & 5 \\
\hline
\end{tabular}

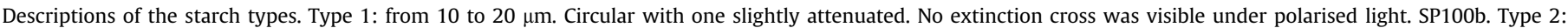

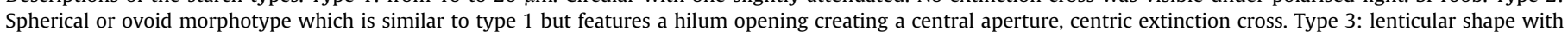

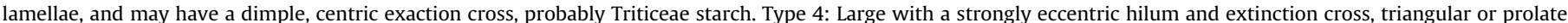

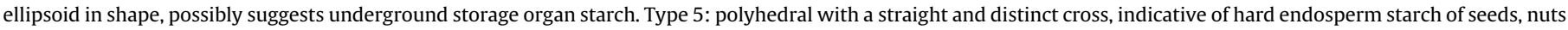

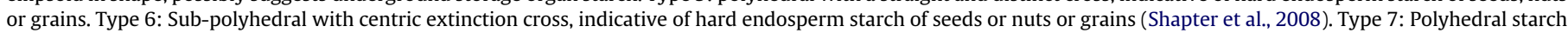

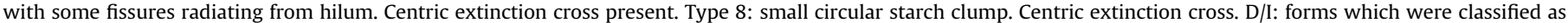

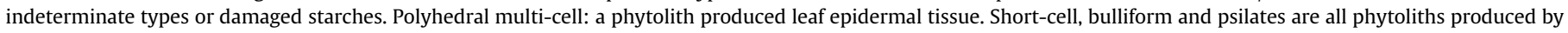
the grass family. 

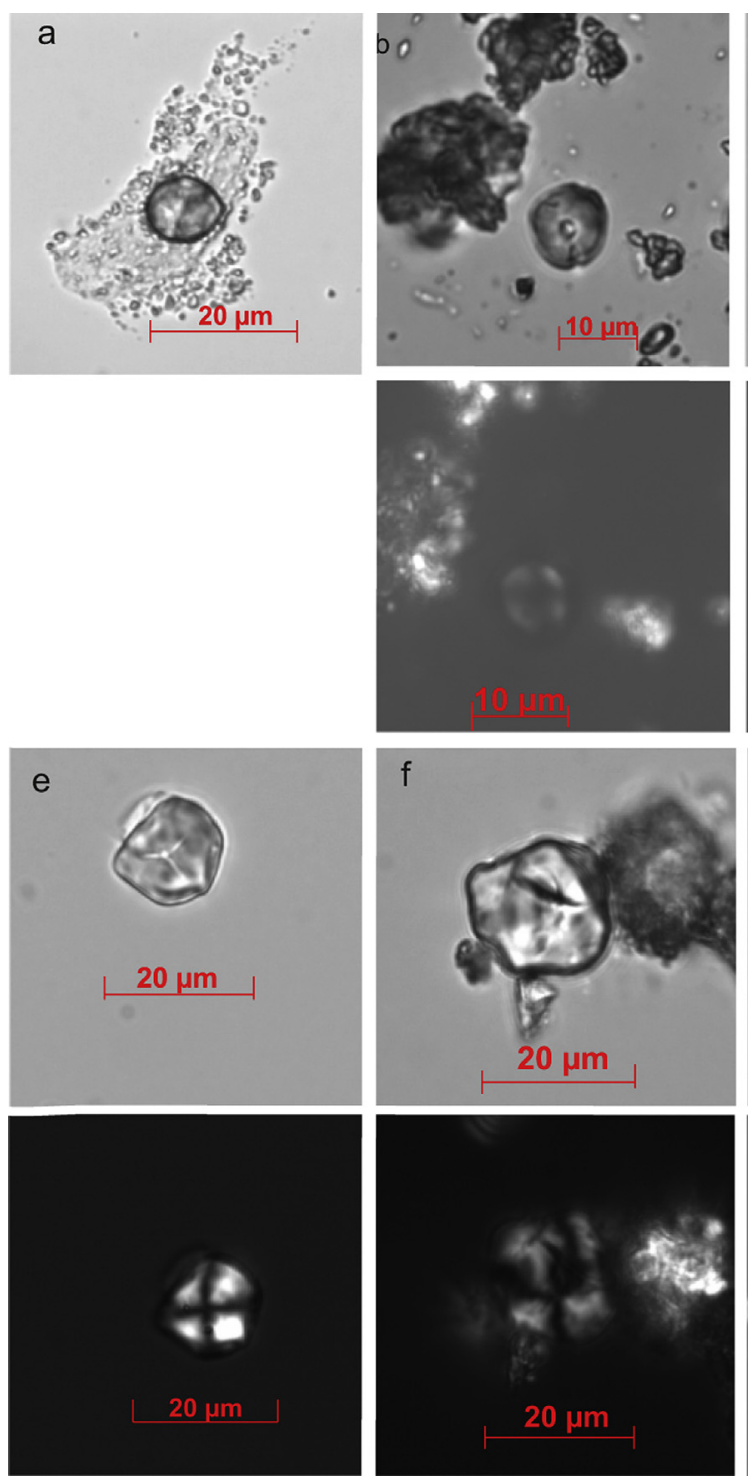
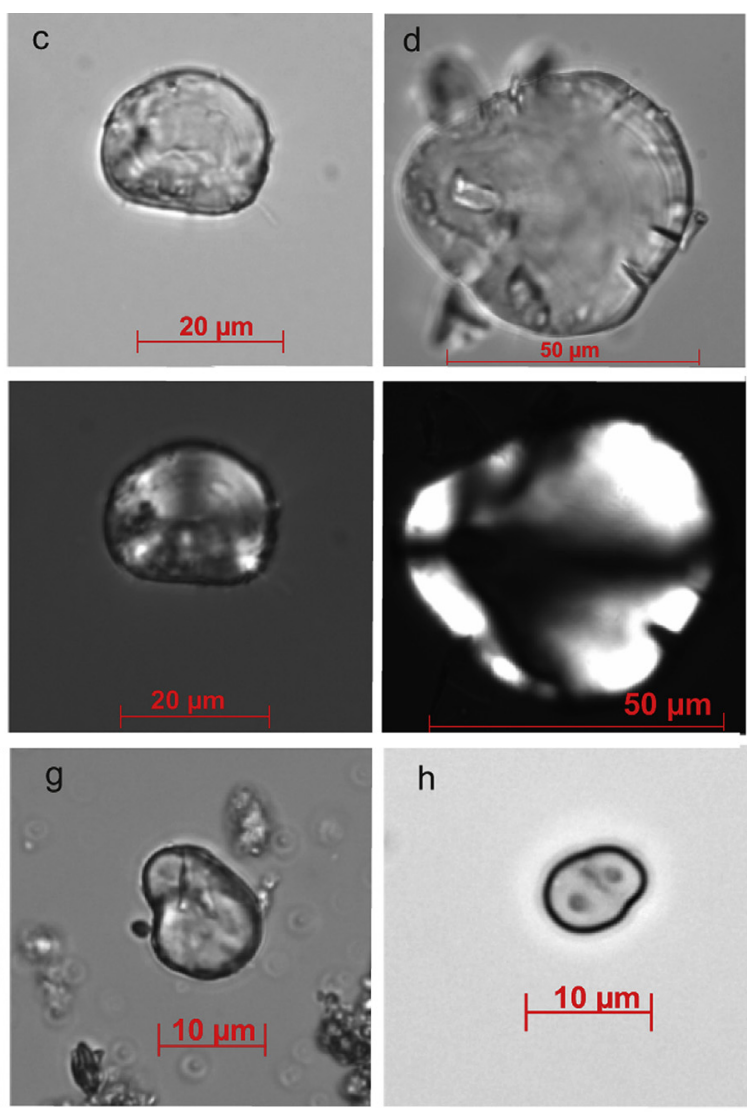

$\mathrm{h}$
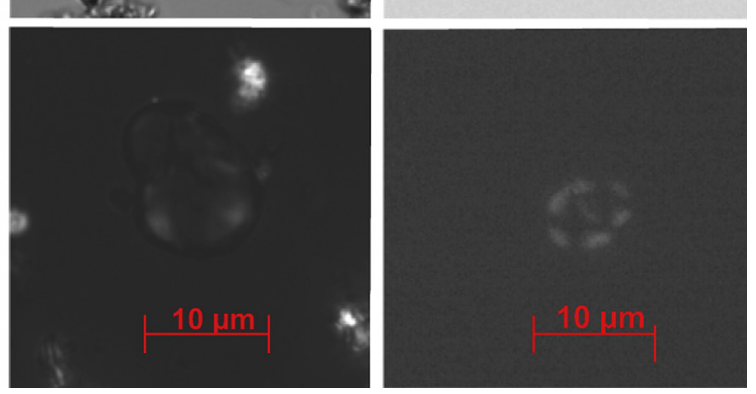

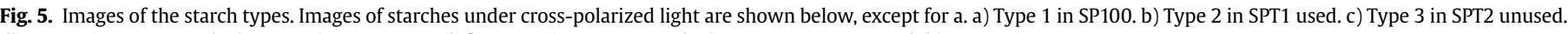
d) Type 4 in SPT unused. e) Type 5 in SPT7 unused. f) Type 6 in SPT4 unused. g) Type 7 I SPT6 unused. h) Type 8 in SP74.

is in part influenced by diet, with carbohydrate-rich diets often inducing more caries (Mandel, 1979). Though the presence of caries on Neanderthal teeth may be more complex than a product of diet (Sołtysiak, 2012), the rarity of Neanderthal dental pathologies is usually attributed to their heavy consumption of meat. Thus, the pathology of Sima de las Palomas also gives support to higher than average consumption of carbohydrates in this group of Neanderthals (Walker et al., 2011c).
However, the availability of energy-rich plants would likely have been largely seasonal. Targeted exploitation of nutrient-rich plants may not have been an effective strategy in certain seasons and environments, for example in dry inland areas in winter/spring. The finding of a variety of plants on Neanderthal teeth suggests they were using the environment comparably to later, modern human foragers. During the succeeding Upper Palaeolithic and Epipalaeolithic periods, hunter-gatherers in southeastern Iberia

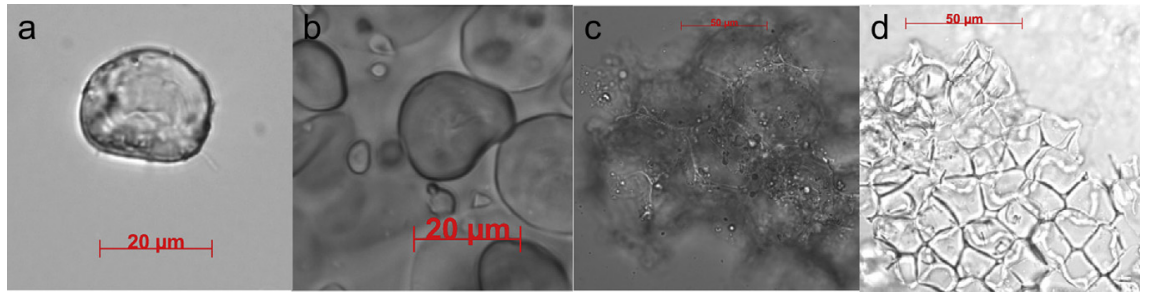

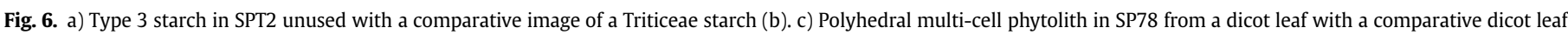
phytolith (d). 
consumed some quantities of grass seeds (Aura et al., 2005). Although our results show at least grass seeds may have been utilised since the Middle Palaeolithic, we cannot rule out further overlap in gathered plant foods with later foragers.

\section{Conclusions}

Faunal analysis suggests diverse Neanderthal hunting and site occupation behaviours, which probably varied in response to local or global climate variation. There is some evidence from coastal sites of minor consumption of marine resources, but terrestrial animals still make up the largest component of the faunal profile at all sites and through all time periods. This is consistent with the isotope evidence, which indicates overwhelming consumption of terrestrial protein sources, as is common among Neanderthals from other areas of Europe. There is some evidence to suggest that Neanderthals consumed a variety of plant foods, but it is likely that these plants were not a dominant proportion of the diet, and may have been eaten only during certain seasons.

Overall, these results suggest that Neanderthals living in the warmer, wetter environments of Mediterranean Iberia were predominantly hunters of medium and large-bodied prey. Although this pattern is similar to those seen in other areas of Europe, the evidence for consumption of small game, aquatic resources and plant foods allows us to conclude that Neanderthal dietary behaviour was to a certain degree influenced by environmental factors and new potential food resources, and therefore not as rigid as previously considered.

\section{Acknowledgments}

Part of this research was funded by the Research Group on Plant Foods in Hominin Dietary Ecology and the Department of Human Evolution (Prof. Jean-Jacques Hublin) of the Max-Planck Institute for Evolutionary Anthropology. Part of this research formed part of the project "Paleolítico medio final y Paleolítico superior inicial en la región central mediterránea ibérica (Valencia y Murcia) (HAR 2011-24878)", and was funded by the Ministerio de Ciencia y Tecnología (Spain). D.C.S.G. thanks Michael P. Richards for his comments on the isotope part of the text. All authors thank the reviewers for their useful comments.

\section{References}

Adler, D.S., Bar-Oz, G., 2009. Seasonal patterns of prey acquisition and inter-group competition during the Middle and Upper Palaeolithic of the Southern Caucasus. In: Hublin, J.J., Richards, M.P. (Eds.), The Evolution of Hominin Diets: Integrating Approaches to the Study of Palaeolithic Subsistence. Springer Science, New York, pp. 127-140.

Adler, D.S., Bar-Oz, G., Belfer-Cohen, A., Bar-Yosef, O., 2006. Ahead of the Game: Middle and Upper Palaeolithic hunting behaviors in the southern Caucasus. Current Anthropology 47, 89-118.

Albert, R.M., Lavi, O., Estroff, L., Weiner, S., Tsatskin, A., Ronen, A., Lev-Yadun, S 1999. Mode of occupation of Tabun Cave, Mt Carmel, Israel during the Mousterian period: a study of the sediments and phytoliths. Journal of Archaeological Science 26 (10), 1249-1260.

Albert, R.M. Weiner, S., Bar-Yosef, O., Meignen, L., 2000. Phytoliths in the Middle Palaeolithic deposits of Kebara Cave, Mt Carmel, Israel: study of the plant materials used for fuel and other purposes. Journal of Archaeological Science 27 (10), 931-947.

Ambrose, S.H., 1993. Isotopic analysis of paleodiets: methodological and interpretative considerations. In: Stanford, M.K. (Ed.), Investigations of Ancient Human Tissue: Chemical Analyses in Anthropology. Gordon and Breach Science Publishers, Langhorne, pp. 59-130.

Ambrose, S.H., Norr, L., 1993. Experimental evidence for the relationship of the carbon isotope ratios of whole diet and dietary protein to those of bone collagen and carbonate. In: Lambert, J.B., Gruppe, G. (Eds.), Prehistoric Human Bone: Archaeology at the Molecular Level. Springer Verlag, Berlin, pp. 1-37.

Armitage, P.L., 1975. The extraction and identification of opal phytoliths from the teeth of ungulates. Journal of Archaeological Science 2, 187-197.
Arsuaga, J.L., Bermúdez de Castro, J.M., 1984. Estudio de los restos humanos del yacimiento de la Cova del Tossal de la Font (Villafamés, Castelló). Cuadernos de Prehistoria y Arqueología Castellonenses 10, 19-34.

Arsuaga, J.L., Gracia, A., Martínez, I., Bermúdez de Castro, J.M., Rosas, A., Villaverde, V., Fumanal, M.P., 1989. The human remains from Cova Negra (Valencia, Spain) and their place in European Pleistocene human evolution. Journal of Human Evolution 18, 55-92.

Arsuaga, J.L., Villaverde, V., Quam, R., Martínez, I., Carretero, J.M., Lorenzo, C., Gracia, A., 2006. New Neandertal remains from Cova Negra (Valencia, Spain). Journal of Human Evolution 52, 31-58.

Aura, J.E., Carrión, Y., Estrelles, E., Jordà, G.P., 2005. Plant economy of huntergatherer groups at the end of the last Ice Age: plant macroremains from the cave of Santa Maira (Alacant, Spain) ca. 12000-9000 BP. Vegetation History and Archaeobotany 14 (4), 542-550.

Aura, J.E., Villaverde, V., Pérez Ripoll, M., Martínez Valle, R., Guillem, P.M., 2002. Big game and small prey: Paleolithic and Epipaleolithic economy from Valencia (Spain). Journal of Archaeological Method and Theory 9 (3), 215-267.

Badal, E., Villaverde, V., Zilhao, J., 2012. Middle Palaeolithic wood charcoal from three sites in south and west Iberia: biogeographic implications. Saguntum Extra 13, 13-24.

Barandiarán, I., Martí, B., Del Rincón, M.A., Maya, J.L., 2012. Prehistoria de la península Ibérica. Ariel Prehistoria, Barcelona.

Barroso, C., Bailon, S., Guennouni, K. El, Desclaux, E., 2006a. Les lagomorphes (Mammalia, Lagomorpha) du Pléistocène supérieur de la Grotte du Boquete de Zafarraya. In: Barroso, C., de Lumley, H. (Eds.), La grotte du Boquete de Zafarraya (Málaga, Andalousie). Consejería de Cultura de la Junta de Andalucía, Málaga, pp. 893-926.

Barroso, C., Hernández, F., Vilette, P., 2006b. Les oiseaux (aves) du Pléistocène Supéireur de la Grotte du Boquete de Zafarraya. Étude comparée avec les sites du Pléistocène supérieur ancien du Bassin Méditerranéen. In: Barroso, C., de Lumley, H. (Eds.), La grotte du Boquete de Zafarraya (Málaga, Andalousie). Consejería de Cultura de la Junta de Andalucía, Málaga, pp. 1023-1052.

Barroso, C., Marchi, F., Abdessadok, S., Bailón, S., Desclaux, E., Gregoire, S., Hernandez Carrasquillas, F., Lacombat, F., Lebreton, V., Lecervoisier, B., Moigne, A.M., Perrenoud, C., Renault-Miskovsky, J., Riquelme Cantal, J.A., Rodriguez Vidal, J., Saos, T., Vernet, J.L., Vilette, P., 2006c. Contexte paléoécologique, paléoclimatique et paléogéographique des Néandertaliens de la grotte du Boquete de Zafarraya. In: Barroso, C., de Lumley, H. (Eds.), La grotte du Boquete de Zafarraya (Málaga, Andalousie). Consejería de Cultura de la Junta de Andalucía, Málaga, pp. 1127-1166.

Barton, R.N.E., Currant, A.P., Fernandez-Jalvo, Y., Finlayson, J.C., Goldberg, P. Macphail, R., Pettitt, P.B., Stringer, C.B., 1999. Gibraltar Neanderthals and results of recent excavations in Gorham's, Vanguard and Ibex caves. Antiquity 73, 13-23.

Bird, D.W., O'Connell, J.F., 2006. Behavioral ecology and archaeology. Journal of Archaeological Research 14, 143-188.

Blasco, R., 2008. Human consumption of tortoises at Level IV of Bolomor Cave (Valencia, Spain). Journal of Archaeological Science 35, 2839-2848.

Blasco, R., 2011. La amplitud de la dieta cárnica en el Pleistoceno medio peninsular: una aproximación a partir de la Cova del Bolomor (Tavernes de la Valldigna, Valencia) y del subnivel C10-1 de Gran Dolina (Sierra de Atapuerca, Burgos). Universitat Rovira i Virgili, Tarragona. (Doctoral thesis).

Blasco, R., Fernández Peris, J., 2009. Middle Pleistocene bird consumption at level XI of Bolomor cave (Valencia, Spain). Journal of Archaeological Science 36, 22132223.

Blasco, R., Férnandez Peris, J., 2010. Los refugios ocasionales de carnívoros en contextos arqueológicos. El ejemplo del nivel X de la Cova del Bolomor (Tavernes de la Valldigna, Valencia). In: Actas de la primera reunión de científicos sobre cubiles de hiena en los yacimientos arqueológicos de la Península ibérica. Zona Arqueológica, vol. 13, pp. 198-212. Alcalá de Henares.

Blasco, R., Fernández Peris, J., 2012a. A uniquely broad spectrum diet during the Middle Pleistocene at Bolomor Cave (Valencia, Spain). Quaternary International 252, 16-31.

Blasco, R., Fernández Peris, J., 2012b. Small and large game: human use of diverse faunal resources al level IV of Bolomor Cave (Valencia, Spain). Comptes Rendus Palevol 11, 265-282.

Blasco, R., Fernández Peris, J., Rosell, J., 2008. Estrategias de subsistencia en los momentos finales del Pleistoceno medio: El nivel XII de la Cova del Bolomor (La Valldigna, Valencia). Zephyrus 62, 63-80.

Blasco, R., Rosell, J., Domínguez-Rodrigo, M., Lozano, S., Pastó, I., Riba, D., Vaquero, M., Fernández Peris, J., Arsuaga, J.L., Bermúdez de CAstro, J.M., Carbonell, E., 2013. Learning by heart: cultural patterns in the faunal processing sequence during the Middle Pleistocene. PLoS ONE 8 (2), e55863.

Bocherens, H., Drucker, D., 2006. Dietary competition between Neanderthals and Modern Humans: insights from stable isotopes. In: Conard, N. (Ed.), When Neanderthals and Modern Humans Met, Publications in Prehistory. KernsVerlag, Tübingen, pp. 129-143.

Bocherens, H., Drucker, D., Billiou, D., Patou-Mathis, M., Vandermeersch, B., 2005. Isotopic evidence for diet and subsistence pattern of the Saint-Césaire I Neanderthal: review and use of a multi-source mixing model. Journal of Human Evolution 49, 71-87.

Boyadjian, C.H.C., Eggers, S., Reinhard, K., 2007. Dental wash: a problematic method for extracting microfossils from teeth. Journal of Archaeological Science 34, $1622-1628$.

Brown, K., Fa, D.A., Finlayson, G., Finlayosn, C., 2011. Small game and marine resource exploitation by Neanderthals: the evidence from Gibraltar. In: 
Bicho, N., Haws, J. (Eds.), Trekking the Shore: Changing Coastlines and the Antiquity of Coastal Settlement. Interdisciplinary Contribution to Archaeology. Springer, New York, pp. 247-271.

Campillo, D., Subirà, M.E., Chimenos, E., Aparicio, J., Pérez, A., Vila, S., 2002. Estudi de les restes humanes de la campanya 2000 de la Cova Foradâ (Oliva, València). Cypsela 14, 205-210.

Carrión, J.S., 1992. A palaecological study in the Western Mediterranean area. The Upper Pleistocene pollen record from Cova Beneito (Alicante, Spain). Palaeogeography, Palaeoclimatology, Palaeoecology 92, 1-14.

Carrión, J.S., Yll, E.I., Walker, M.J., Legaz, A.J., Chaín, C.A., López, A., 2003. Glacial refugia of temperate, Mediterranean and Ibero-North African flora in southeastern Spain: new evidence from cave pollen at two Neanderthal man sites. Global Ecology and Biogeography 12, 119-129.

Cerling, T.E., 1999. Palaeorecords of $\mathrm{C}_{4}$ plants and ecosystems. In: Sage, R.F., Monson, R.K. (Eds.), C 4 Plant Biology. Academic Press, London, pp. 313-373.

Chisholm, B.S., Nelson, D.E., Schwarcz, H.P., 1982. Stable carbon isotope ratios as a measure of marine versus terrestrial protein in ancient diets. Science $216,1131-$ 1132.

Colonese, A.C., Mannino, M.A., Bar-Yosef, D.E., Fa, D.A., Finlayson, J.C., Lubell, D. Stiner, M.C., 2011. Marine mollusc exploitation in Mediterranean prehistory: an overview. Quaternary International 239 (1-2), 86-103.

Cortés-Sánchez, M., Morales-Muñiz, A., Simón-Vallejo, M.D., Lozano-Francisco, M.C., Vera-Peláez, J.L., Finlayson, C., Rodríguez-Vidal, J., Delgado-Huertas, A., JiménezEspejo, F.J., Martínez-Ruiz, F., Martínez-Aguirre, M.A., Pascual-Granged, A.J., Bergadà-Zapata, M.M., Gibaja-Bao, J.F., Riquelme-Cantal, J.A., López-Sáez, J.A., Rodrigo-Gámiz, M., Sakai, S., Sugisaki, S., Finlayson, G., Fa, D.A., Bicho, N.F., 2011. Earliest known use of marine resources by Neanderthals. PLoS ONE 6 (9). http:// dx.doi.org/10.1371/journal.pone.0024026.

De Niro, M.J., 1985. Postmortem preservation and alteration of in vivo bone collagen isotope ratios in relation to palaeodietary reconstruction. Nature 317, 806-809.

De Niro, M.J., Epstein, S., 1981. Influence of diet on the distribution of nitrogen isotopes in animals. Geochimica et Cosmochimica Acta 49, 97-115.

Delpech, F., Guérin, C., 1996. Paléoenvironnement: L'animal, le milieu, le climat. In: Guérin, C., Patou-Mathis, M. (Eds.), Les grands mammifères plio-pléistocènes d'Europe. Masson, Paris, pp. 243-253.

Delpech, F., Grayson, D.K., 2007. Chasse et subsistance aux temps de Neandertal. In: Vandermeersch, B. (Ed.), Les Néandertaliens. Biologie et cultures. Éditions du CTHS, Paris, pp. 181-198. Documents préhistoriques 23.

Domènech, E., 2001. Cova Beneito (Muro, Alacant). In: Villaverde, V. (Ed.), De Neandertales a Cromañones. El inicio del poblamiento humano en tierras valencianas. Universitat de València, Valencia, pp. 403-406.

Eixea, A., Villaverde, V., Zilhão, J., 2011. Aproximación al aprovisionamiento de materias primas líticas en el yacimeinto del Paleolítico medio del Abrigo de la Quebrada (Chelva, Valencia). Trabajos de Prehistoria 68 (1), 65-78.

Eixea, A., Villaverde, V., Zilhão, J., Sanchis, A., Morales, J.V., Real, C., Bergdadà, M., 2013. El nivel IV del Abrigo de la Quebrada (Chelva, Valencia). Análisis microespacial y valoración del uso del espacio en los yacimientos del Paleolítico medio valenciano. Mainake (in press).

El Zaatari, S.E., Grinec, F.E., Ungar, P.S., Hublin, J.J., 2011. Ecogeographic variation in Neandertal dietary habits: evidence from occlusal molar microwear texture analysis. Journal of Human Evolution 61 (4), 411-424.

Fa, J.E., Stewart, J.R., Lloveras, L., Vargas, J.M., 2013. Rabbits and hominin survival in Iberia. Journal of Human Evolution 64 (4), 233-241.

Fernández Peris, J., 2007. La Cova del Bolomor (Tavernes de la Valldigna, Valencia). In: Las industrias líticas del Pleistoceno medio en el ámbito del Mediterráneo peninsular. Serie Trabajos Varios 108. Servicio de Investigación Prehistórica de la Diputación de Valencia, Valencia.

Fernández Peris, J., Villaverde, V., 2001. E, Paleolítico medio: el tiempo de los neandertales. Periodización y características. In: Villaverde, V. (Ed.), De Neandertales a Cromañones. El inicio del poblamiento humano en las tierras valenciana. Universitat de València, Valencia, pp. 147-176.

Fernández Peris, J., Barciela, V., Blasco, R., Cuartero, F., Sañudo, P., 2008. El Paleolítico Medio en el territorio valenciano y la variabilidad tecno-económica de la Cova del Bolomor. Treballs d'Arqueologia 14, 141-169.

Fernández-Peris, J., Barciela, V., Blasco, R., Cuartero, F., Fluck, H., Sañudo, P., Verdasco, C., 2012. The earliest evidence of hearths in Southern Europe: the case of Bolomor Cave (Valencia, Spain). Quaternary International 247, 267-277.

Fischler, C., 2001. L'Homnivore. Odile Jacob Poches, Paris.

Finlayson, C., 2008. On the importance of coastal areas in the survival of Neanderthal populations during the Late Pleistocene. Quaternary Science Reviews 27 (23), 2246-2252.

Finlayson, C., Pacheco, F.G., Rodríguez-Vidal, J., Fa, D.A., Gutierrez López, J.M., Pérez, A.S., Finlayson, G., Allue, E., Baena Preysler, J., Cáceres, I., Carrión, J.S., Fernández Jalvo, Y., Gleed-Owen, C.P., Jimenez Espejo, F.J., López, P., López Sáez, J.A., Riquelme Cantal, J.A., Sánchez Marco, A., Giles Guzman, F., Brown, K., Fuentes, N., Valarino, C.A., Villalpando, A., Stringer, C.B., Martinez Ruiz, F., Sakamoto, Y., 2006. Late survival of Neanderthals at the southernmost extreme of Europe. Nature 443 (7113), 850-853.

Fizet, M., Mariotti, A., Bocherens, H., Lange-Badre, B., Vandermeersch, B., Borel, J.P., Bellon, G., 1995. Effect of diet, physiology and climate on carbon and nitrogen isotopes of collagen in a late Pleistocene anthropic paleoecosystem (France, Charente, Marillac). Journal of Archaeological Science 22, 67-79.

Fullagar, R., Field, J., Denham, T., Lentfer, C., 2006. Early and mid Holocene tool-use and processing of taro (Colocasia esculenta), yam (Dioscorea sp.) and other plants at Kuk Swamp in the highlands of Papua New Guinea. Journal of Archaeological Science 33 (5), 595-614.

Galván, B., Hernández, C.M., Alberto, V., Barro, A., Garralda, M.D. Vandermeersch, B., 2001. El Salt (Serra Mariola, Alacant). In: Villaverde, V. (Ed.) De Neandertales a Cromañones. El inicio del poblamiento humano en tierras valencianas. Universitat de València, Valencia, pp. 397-402.

Galván, B., Hernández, C.M., Ortega, F., 2006. Territorio y producción lítica en los valles de Alcoy (Alicante) durante el Paleolítico Medio. In: Martínez, G., Morgado, A., Alfonso, J.A. (Coords.), Sociedades prehistóricas, recursos abióticos y territorio. Fundación Ibn al-Jatib de Estudios de Cooperación Cultural, Granada, pp. 135-158.

Galván, B., Hernández, C.M., Francisco, M.I., 2007-2008. Elementos líticos apuntados en el Musteriense alcoyano. El Abric del Pastor (Alicante). Veleia 24-25, 367383.

Galván, B., Hernández, C.M., Ortega, F., Molina, F.J., Tarriño, A., 2008. La producción lítica del Abric del Pastor (Alcoi, Alicante). Un ejemplo de variabilidad musteriense. Tabona 17, 11-61.

Gamble, C., 1999. The Palaeolithic Societies of Europe. Cambridge University Press, Cambridge.

Gaudzinski-Windheuser, S., Roebroeks, W., 2011. On Neanderthal subsistence in Last Interglacial forested environments in Northern Europe. In: Conard, N.J. Richter, J. (Eds.), Neanderthal Lifeways, Subsistence and Technology. Springer, New York, pp. 61-71.

Gómez, A., Lunt, D.H., 2007. Refugia within refugia: patterns of phylogeographic concordance in the Iberian Peninsula. In: Weiss, S., Ferrand, N. (Eds.) Phylogeography of Southern European Refugia. Springer, New York, pp. 155-188.

Gómez de la Rua, D., Mallol, C., Galván, B., Hernández, C., 2010. Una vision geoarqueológica general del yacimiento musteriense de El Salt (Alcoy, Alicante) a partir de la micromorfología. Recerques del Museu d'Alcoi 19, 19-32.

Guérin, C., Patou-Mathis, M., 1996. Les grands mammifères plio-pléistocènes d'Europe. Masson, Paris.

Guillem, P.M., 2000. Secuencia climática del Pleistoceno medio final y del Pleistoceno superior inicial en la fachada central mediterránea a partir de micromamíferos (Rodentia e Insectivora). Saguntum 32, 9-29.

Hardy, B.L., 2004. Neanderthal behavior and stone tool function at the Middle Palaeolithic site of La Quina, France. Antiquity 78, 547-565.

Hardy, B.L., 2010. Climatic variability and plant food distribution in Pleistocene Europe: implications for Neanderthal diet and subsistence. Quaternary Science Reviews 29 (5-6), 662-679.

Hardy, B.L., Moncel, M.H., 2011. Neanderthal use of fish, mammals, birds, starchy plants and wood 125-250,000 years ago. PLoS ONE 6 (8), e23768.

Hardy, B.L., Kay, M., Marks, A.E., Monigal, K., 2001. Stone tool function at the paleolithic sites of Starosele and Buran Kanya III, Crimea: behavioral implications. Proceedings of the National Academy of Sciences of the United States of America 98, 10972-10977.

Hardy, K., Buckley, S., Collins, M.J., Estalrrich, A., Brothwell, D., Copeland, L., GarcíaTabernero, A., García-Vargas, S., de la Rasilla, M., Lalueza-Fox, C., Huguet, R., Bastir, M., Santamaría, D., Madella, M., Wilson, J., Fernández Cortés, A., Rosas, A., 2012. Neanderthal medics? Evidence for food, cooking, and medicinal plants entrapped in dental calculus. Naturwissenschaften 99 (8), 617-626.

Haws, J.A., Funk, C.L., Benedetti, M.M., Bicho, N.F., Daniels, J.M., Minckley, T.A., Denniston, R.F., Jeraj, M., Gibaja, J.F., Hockett, B.S., Forman, S.L., 2011. Paleolithic landscapes and seascapes of the West Coast of Portugal. In: Bicho, N.F., Haws, J.A., Davis, L.G. (Eds.), Trekking the Shore, Changing Coastlines and the Antiquity of Coastal Settlement. Springer, New York, pp. 203-246.

Hedges, R.E.M., Clement, J.G., Thomas, C.D.L., O'Connell, T.C., 2007. Collagen turnover in the adult femoral mid-shaft: modeled from anthropogenic radiocarbon tracer measurements. American Journal of Physical Anthropology 133, 808816.

Henry, A.G., Piperno, D.R., 2008. Using plant microfossils from dental calculus to recover human diet: a case study from Tell al-Raqā'i, Syria. Journal of Archaeological Science 35 (7), 1943-1950.

Henry, A.G., Brooks, A.S., Piperno, D.R., 2011. Microfossils in calculus demonstrate consumption of plants and cooked foods in Neanderthal diets (Shanidar III Iraq; Spy I and II, Belgium). Proceedings of the National Academy of Sciences of the United States of America 108 (2), 486-491.

Henry, D.O., Hall, S.A., Hietala, H.J., Demidenko, Y.E., Usik, V.I., Rosen, A.M., Thomas, P.A., 1996. Middle Paleolithic behavioral organization: 1993 excavation of Tor Faraj, Southern Jordan. Journal of Field Archaeology 23, 31-53.

Henry, D.O., Hietala, H.J., Rosen, A.M., Demidenko, Y.E., Usik, V.I., Armagan, T.L., 2004. Human behavioral organization in the Middle Paleolithic: were Neanderthals different? American Anthropologist 106, 17-31.

Hewitt, G.M., 1999. Post-glacial re-colonization of European biota. Biological Journal of the Linnean Society 68 (1-2), 87-112.

Hockett, B.S., 2012. The consequences of Middle Paleolithic diets on pregnant Neanderthal women. Quaternary International 264, 78-82.

Hockett, B.S., Haws, J., 2003. Nutritional ecology and diachronic trends in Paleolithic diet and health. Evolutionary Anthropology 12 (5), 211-216.

Hockett, B., Haws, J.A., 2005. Nutritional ecology and the human demography of Neandertal extinction. Quaternary International 137 (1), 21-34.

Hockett, B.S., Haws, J., 2009. Continuity in animal resource diversity in the Late Pleistocene human diet of central Portugal. Before Farming 2009/2 Article 2,115.

Hoffecker, J.F., 2009. Neanderthal and modern human diet in Eastern Europe. In: Hublin, J.J., Richards, M.P. (Eds.), The Evolution of Hominin Diets: Integrating 
Approaches to the Study of Palaeolithic Subsistence. Springer, New York, pp. 87-98.

Howland, M.R., Corr, L.T., Young, S.M.M., Jones, V., Jim, S., van der Merwe, N.J. Mitchell, A., Evershed, R.P., 2003. Expression of the dietary isotope signal in the compound-specific $\delta^{13} \mathrm{C}$ values of pig bone lipids and amino acids. International Journal of Osteoarchaeology 13, 54-65.

Iacumin, P., Nikolaev, V., Ramigni, M., 2000. C and N stable isotope measurements on Eurasian fossil mammals, 40000 to 10000 years BP: herbivore physiologies and palaeoenvironmental reconstruction. Palaeogeography, Palaeoclimatology, Palaeoecology 163, 33-47.

ICSN, 2011. The International Code for Starch Nomenclature. http://fossilfarm.org/ ICSN/Code.html (accessed 04.03.13.).

Iturbe, G., Fumanal, M.P., Carrión, J.S., Cortell, E., Martínez Valle, R., Guillem, P.M. Garralda, M.D., Vadermeersch, B., 1993. Cova Beneito (Muro, Alicante). Una perspectiva interdisciplinar. Recerques del Museu d'Alcoi 2, 23-88.

Jennings, R., Finlayson, C., Fa, D., Finlayson, G., 2011. Southern Iberia as a refuge for the last Neanderthal populations. Journal of Biogeography 38, 1873-1885.

Jim, S., Jones, V., Ambrose, S.H., Evershed, R.P., 2006. Quantifying dietary macronutrient sources of carbon for bone collagen biosynthesis using natural abundance stable carbon isotope analysis. British Journal of Nutrition 95, 1055-1062.

Jones, M., 2009. Moving north: archaeobotanical evidence for plant diet in Middle and Upper Paleolithic Europe. In: Hublin, J.J., Richards, M.P. (Eds.), The Evolution of Hominin Diets: Integrating Approaches to the Study of Palaeolithic Subsistence. Springer, New York, pp. 171-180.

Katzenberg, M.A., 2000. Stable istope analysis: a tool for studying past diet, demography and life history. In: Katzenberg, M.A., Saunders, S.R. (Eds.), Biological Anthropology of the Human Skeleton. Willey-Liss, New York, pp. 305328 .

Krause, J., Lalueza-Fox, C., Orlando, L., Enard, W., Green, R.E., Burbano, H.A., Hublin, J.J., Hänni, C., Fortea, J., de la Rasilla, M., Bertanpetit, J., Rosas, A. Pääbo, S., 2007. The derived FOXP2 wariant of modern humans was shared with Neandertals. Current Biology 17, 1908-1912.

Kuhn, S.L., Stiner, M.C., 2006. What's a mother to do? The division of labor among Neandertals and modern humans in Eurasia. Current Anthropology 47, 953-980.

Lee-Thorp, J.A., 2008. On isotopes and old bones. Archaeometry 50, 925-950.

Lee-Thorp, J.A., Sponheimer, M., 2006. Contributions of biogeochemistry to understanding hominin dietary ecology. Yearbook of Physical Anthropology 49, 131148.

Lev, E., Kislev, M.E., Bar-YOsef, O., 2005. Mousterian vegetal food in Kebara cave, Mt. Carmel. Journal of Archaeological Science 32 (3), 475-484.

Lieberman, D.E., 1993. The rise and fall of seasonal mobility among hunter-gatherers. Current Anthropology 34, 599-631.

Lieberman, D.E., Shea, J.J., 1994. Behavioral differences between archaic and modern humans in the Levantine Mousterian. American Anthropologist 96, 300-332.

Loy, T., Barton, H., 2005. Post-Excavation contamination and measures for prevention. In: Torrence, R., Barton, H. (Eds.), Ancient Starch Research. Left Coast Press, Walnut Creek, p. 165

MacDonald, K., Roebroeks, W. Verpoorte, A, 2009. An energtics perspective on the Neandertal record. In: Hublin, J.J., Richards, M.P. (Eds.), The Evolution of Hominin Diets: Integrating Approaches to the Study of Palaeolithic Subsistence. Springer, New York, pp. 211-220.

Madella, M., Alexandre, A., Ball, T., 2005. International code of phytolith nomenclature 1.0. Annals of Botany 96, 253-260.

Mandel, I.D., 1979. Dental caries: although we seem to be paying for the sweet life through the teeth, resistance to caries is possible, both as a natural and an induced phenomenon. American Scientist 67 (6), 680-688.

Marrero, E., Hernández, C.M., Galván, B., 2011. El análisis espacial en el estudio de las secuencias de facies arqueosedimentarias. Criterios para identificar eventos de ocupación en yacimientos del Paleolítico medio: El Salt y el Abric Pastor (Alcoy, Alicante, España). Recerques del Museu d'Alcoi 20, 7-32.

Martínez Valle, R., 2009. Restos óseos de macromamíferos y aves. In: Los primeros pobladores de La Costera: los neandertales de la Cova Negra de Xàtiva. In: Villaverde, V., Pérez Ballester, J., Lledó, A.C. (Coords.), Historia de Xàtiva. Prehistoria, Arqueología y Antigüedad, vol. I, Universitat de València, Xàtiva, pp. 59-83.

Martínez Valle, R., Iturbe, G., 1993. La fauna de Cova Beneito. Recerques del Museu d'Alcoi 2, 23-88.

Minagawa, M., Wada, E., 1984. Stepwise enrichment of ${ }^{15} \mathrm{~N}$ along food chains: further evidence and the relation between ${ }^{15} \mathrm{~N}$ and animal age. Geochimica et Cosmochimica Acta 48, 1135-1140.

Molina, F.J., Tarriño, A., Galván, B., Hernández, C., 2010. Áreas de aprovisionamiento de sílex en el Paleolítico medio en torno al Abric del Pastor (Alcoi, Alicante) Recerques del Museu d'Alcoi 19, 65-80.

Montes Bernárdez, R., 1988. Restos malacológicos y paleontológicos del Musteriense en la costa de Murcia (Sureste de España). Anales de Prehistoria y Arqueología 4, 27-31.

Montes Bernárdez, R., 1989. La grotte "de Los Aviones" Cartagena (Espagne). Bulletin de la Société Préhistorique Française 86 (2), 40-44.

Montes Bernárdez, R., 1991. Excavaciones arqueológicas en el yacimiento paleolitico de Cueva Perneras. Memoria de las campañas cuarta y quinta. Memorias de Arqueología de la Región de Murcia 2, 11-33.

Montes Bernárdez, R., 1992. Consideraciones generales sobre el Musteriense en el sur y sureste español (Murcia, Albacete y Andalucía). Verdolay 4, 7-13.

Morales, J.V., Sanchis, A., 2009. The quaternary fossil record of the genus Testudo in the Iberian Peninsula. Archaeological implications and diacronic distribution in the western Mediterranean. Journal of Archaeological Science 36, 1152-1162.
Moriel, A., 1985. Aplicación de una metodología de studio de las funciones en las raederas de Cova Negra (Xàtica, Valencia). Cuadernos de Prehistoria y Arqueología Castellonenses 11, 17-86.

Mota, J.F., Pérez-García, F.J., Jiménez, M.L., Amate, J.J., Peñas, J., 2002. Phytogeographical relationships among high mountain areas in the Baetic Ranges (South Spain). Global Ecology and Biogeography 11, 497-504.

O'Connell, J.F., 2006. How did modern humans displace Neanderthals? Insights from hunter-gatherer ethnography and archaeology. In: Conard, N.J. (Ed.), When Neanderthals and Modern Humans Met. Kerns Verlag, Tübingen, pp. 43-65.

Olària, C., Carbonell, E., Ollé, A., Allué, E., Bennàsar, L., Bischoff, J.L., Burjachs, F., Cáceres, I., Expósito, I., López- Polin, L., Saladié, P., Vergés, J.M., 2004-2005. Noves intervencions al jaciment plistocènic de la Cova de Dalt del Tossal de la Font (Vilafamés, Castellò). Quaderns de Prehistòria i Arqueología de Castellò 24, $9-26$.

Patou-Mathis, M., 2011. Néandertal un grand chasseur. Les Dossiers d'Archéologie 345, 58-61.

Pérez Ripoll, M., 1977. Los mamíferos del yacimiento musteriense de Cova Negra. In: Serie Trabajos Varios 53. Servicio de Investigación Prehistórica de la Diputación de Valencia, Valencia.

Pérez Ripoll, M., Martínez Valle, R., 2001. La caza, el aprovechamiento de las presas y el comportamiento de las comunidades cazadoras prehistóricas. In: Villaverde, V. (Ed.), De Neandertales a Cromañones. El inicio del poblamiento humano en tierras valencianas. Universitat de València, Valencia, pp. 73-98.

Piperno, D.R., Dillehay, T.D., 2008. Starch grains on human teeth reveal early broad crop diet in northern Peru. Proceedings of the National Academy of Sciences of the United States of America 105 (50), 19622-19627.

Richards, M.P., 2002. A brief review of the archaeological evidence for Paleolithic and Neolithic subsistence. European Journal of Clinical Nutrition 56, 12701278.

Richards, M.P., Hedges, R.E.M., 2003. Variations in bone collagen ${ }^{13} \mathrm{C}$ and ${ }^{15} \mathrm{~N}$ values of fauna from Northwest Europe over the last 40,000 years. Palaeogeography, Palaeoclimatology, Palaeoecology 193, 261-267.

Richards, M.P., Schmitz, R.W., 2008. Isotope evidence for the diet of the Neanderthal type specimen. Antiquity $82,553-559$.

Richards, M.P., Trinkaus, E., 2009. Isotopic evidence for the diets of European Neanderthals and early modern humans. Proceedings of the National Academy of Sciences of the United States of America 106, 16034-16039.

Richards, M.P., Pettitt, P.B., Trinkaus, E., Smith, F.H., Paunovic, M., Karavanic, I., 2000. Neandertal diet at Vindija and Neandertal predation: the evidence from stable isotopes. Proceedings of the National Academy of Sciences of the United States of America 97, 7663-7666.

Richards, M.P., Taylor, G., Steele, T., McPherron, S.P., Soressi, M., Jaubert, J., Orschiedt, J., Mallye, J.B., Rendu, W., Hublin, J.J., 2008. Isotopic dietary analysis of a Neanderthal and associated fauna from the site of Jonzac (Charente-Maritime), France. Journal of Human Evolution 55, 179-185.

Rios, J., 2006. Industria lítica y sociedad en la Transición del Paleolítico medio al superior en torno al Golfo de Bizkaia (Doctoral thesis). Universidad de Cantabria, Santander.

Rodríguez, A., Galván, B., Hernández, C., 2002. Contribución del análisis funcional en la caracterización de El Salt como un centro de 121 intervención referencial de las poblaciones neandertalianas en los valles de Alcoi (Alicante). In: Clemente, I., Risch, R., Gibaja, J.F. (Eds.), Análisis Funcional: su aplicación al estudio de sociedades prehistóricas, BAR International Series 1073. Archaeopress, Oxford, pp. 121-132.

Rosen, A.M., 2003. Middle Paleolithic plant exploitation: the microbotanical evidence. In: Henry, D.O. (Ed.), Neanderthals in the Levant: Behavioral Organization and the Beginning of Human Modernity. Continuum International Publishing Group, London, pp. 156-171.

Sage, R.F., Wedin, D.A., Li, M., 1999. The biogeography of $\mathrm{C}_{4}$ photosynthesis: patterns and controlling factors. In: Sage, R.F., Monson, R.K. (Eds.), $\mathrm{C}_{4}$ Plant Biology. Academic Press, London, pp. 313-373.

Saladié, P., Cáceres, I., Ollé, A., Vallverdú, J., Van del Made, J., Vergès, J.M., Bennàsar, M., López-Polín, L., Lorenzo, C., Expósito, I., Burjachs, F., Olària, C., Gusi, F., Carbonell, E., 2010. Primeros resultados tafonómicos de las asociaciones fósiles de la Cova de Dalt del Tossal de la Font (Vilafamés, Castelló). In: Actas de la primera reunión de científicos sobre cubiles de hiena en los yacimientos arqueológicos de la Península ibérica. Zona Arqueológica, vol. 13, pp. 526-537. Alcalá de Henares.

Salazar-García, D.C., 2012. Isótopos, dieta y movilidad en el País Valenciano. Aplicación a restos humanos del Paleolítico medio al Neolítico final. Universitat de València, Valencia. (Doctoral thesis).

Sanchis, A., 2000. Los restos de Oryctolagus cuniculus en las tafocenosis de Bubo Bubo y Vulpes vulpes y su aplicación a la caracterización de registro faunístico arqueológico. Saguntum 32, 31-50.

Sanchis, A., 2012. Los lagomorfos del Paleolítico medio en la vertiente mediterránea ibérica. In: Humanos y otros predadores como agentes de aporte y alteración de los restos óseos en yacimientos arqueológicos. Serie Trabajos Varios 115. Servicio de Investigación Prehistórica de la Diputación de Valencia, Valencia.

Sanchis, A., Fernández Peris, J., 2008. Procesado y consumo antrópico de conejo en la Cova del Bolomor (Tavernes de la Valldigna, Valencia). El nivel XVIIc (ca $350 \mathrm{ka})$. Complutum 19 (1), 25-46.

Sanchis, A., Fernández Peris, J., 2011. Nuevos datos sobre la presencia de Lepus en el Pleistoceno medio y superior del Mediterráneo ibérico: la Cova del Bolomor (Valencia). Saguntum 43, 9-20. 
Sanchis, A., Morales, J.V., Pérez Ripoll, M., 2011. Creación de un referente experimental para el estudio de las alteraciones causadas por dientes humanos sobre huesos de conejo. In: Morgado, A., Baena, J., García, D. (Eds.), La investigación experimental aplicada a la arqueología. Segundo Congreso de Arqueología Experimental, Ronda (Málaga), pp. 343-349.

Sanchis, A., Morales, J.V., Real, C., Eixea, A., Villaverde, V., Zilhao, J., 2013. Los conjuntos faunísticos del Paleolítico medio del Abrigo de la Quebrada (Chelva, Valencia): problemática de estudio, metodología aplicada y síntesis de los primeros resultados. In: Sanchis Serra, A., Pascual Benito, J.L. (Eds.), Animals i Arqueologia Hui. Primeres Jornades d'Arqueozoologia del Museu de Prehistòria de València. Servicio de Investigación prehistórica de la Diputación de Valencia, Valencia, pp. 65-82.

Sañudo, P., Fernández Peris, J., 2007. Análisis espacial del nivel IV de la Cova del Bolomor (La Valldigna, Valencia). Saguntum 39, 9-27.

Sarrión, I., 1990. El yacimiento del Pleistoceno medio de la Cova del Corb (OndaraAlicante). Archivo de Prehistoria Levantina 20, 43-78.

Schoeller, D.A., 1999. Isotope fractionation: why aren't we what we eat? Journal of Archaeological Science 26, 667-673.

Schoeninger, M.J., De Niro, M., 1984. Nitrogen and carbon isotopic composition of bone collagen from marine and terrestrial animals. Geochimica et Cosmochimica Acta 48, 625-639.

Schoeninger, M.J., De Niro, M., Tauber, H., $1983 .{ }^{15 / 14} \mathrm{~N}$ ratios of bone collagen reflect marine and terrestrial components of prehistoric human diet. Science 220, 1381-1383.

Scott, G.R., Gibert, L., 2009. The oldest hand-axes in Europe. Nature 461, 82-85.

Sealy, J., 2001. Body tissue chemistry and paleodiet. In: Brothwell, D.R., Pollard, A.M. (Eds.). Handbook of Archaeological Sciences. Wiley, Chichester, pp. 269-279.

Sepulchre, P., Ramstein, G., Kageyama, M., Vanhaeren, M., Krinner, G., SánchezGoñi, M.F., d'Errico, F., 2007. H4 abrupt event and late Neanderthal presence in Iberia. Earth and Planetary Science Letters 258 (1), 283-292.

Shapter, F.M., Henry, R.J., Lee, L.S., 2008. Endosperm and starch granule morphology in wild cereal relatives. Plant Genetic Resources 6 (2), 85-97.

Sistiaga, A., March, R., Hernández, C., Galván, B., 2011. Aproximación desde la química orgánica al estudio de los hogares del yacimiento del Paleolítico medio de El Salt (Alicante, España). Recerques del Museu d'Alcoi 20, 7-70.

Soler, B., 2003. Estudio de las estructuras de combustión prehistóricas: una propuesta experimental. Cova Negra (Xátiva, Valencia), Ratlla del Bubo (Crevillent, Alicante) y Marolles-sur-Seine (Bassin Parisien, Francia). In: Serie Trabajos Varios 102. Servicio de Investigación Prehistórica de la Diputación de Valencia, Valencia.

Sołtysiak, A., 2012. Comment: low dental caries rate in Neandertals: the result of diet or the oral flora composition? HOMO - Journal of Comparative Human Biology 63 (2), 110-113.

Stiner, M.C., 2006. Middle Palaeolithic subsistence ecology in the Mediterranean region. In: Hovers, E., Kuhn, S.L. (Eds.), Transitions Before the Transition: Evolution and Stability in the Middle Palaeolithic and Middle Stone Age. Springer, New York, pp. 213-231.

Stiner, M.C., Kuhn, S.L., 1992. Subsistence, technology and adaptive variation in Middle Palaeolithic Italy. American Anthropologist, 306-339.

Stiner, M.C., Kuhn, S.L., 2009. Paleolithic diet and the division of labor in Mediterranean Eurasia. In: Hublin, J.J., Richards, M.P. (Eds.), The Evolution of Honinin Dieta: Integrating Approaches to the Study of Palaeolithic Subsistence. Springer Science, pp. $157-170$

Stiner, M.C., Munro, N.D., Surovell, T.A., 2000. The tortoise and the hare: small-game use, the broad-spectru revolution and Palaeolithic demography. Current Anthropology 41, 39-73.

Stringer, C.B., Finlayson, J.C., Barton, R.N.E., Fernández-Jalvo, Y., Cáceres, I., Sabin, R.C., Rhodes, E.J., Currant, A.P., Rodríguez-Vidal, J., Giles-Pacheco, F., Riquelma-Cantal, J.A., 2008. Neanderthal exploitation of marine mammals in Gibraltar. Proceedings of the National Academy of Sciences of the United States of America 105 (38), 14319-14324.

Van der Merwe, N.J., Vogel, J.C., $1978 .{ }^{13} \mathrm{C}$ content of human collagen as a measure of prehistoric diet in Woodland North America. Nature 276, 815-816.

Van Klinken, G.J., 1999. Bone collagen quality indicators for palaeodietary and radiocarbon measurements. Journal of Archaeological Science 26, 687-695.

Villa, P., Lenoir, M., 2006. Hunting weapons of the Middle Stone Age and Middle Palaeolithic: spear points from Sibudu, Rose Cottage and Bouhe-ben. Southern African Humanities 18 (1), 89e122.

Villa, P., Boscato, P., Ranaldo, F., Ronchitello, A., 2009. Stone tools for the hunt: points with impact scars from a Middle Paleolithic site in southern Italy. Journal of Archaeological Science 36, 850-859.
Villaverde, V., 1984. La Cova Negra de Xàtiva y el Musteriense en la región centra del Mediterráneo español. In: Serie Trabajos Varios 79. Servicio de Investigación Prehistórica de la Diputación de Valencia, Valencia.

Villaverde, V., 2006. Los Primeros pobladores de la Costera: Los neandertales de la Cova Negra de Xàtiva. In: Villaverde, V., Pérez-Ballester, J., Lledó, A. (Coords.), Historia de Xàtiva, Prehistoria, Arqueología y Antigüedad, Universitat de València, Xàtiva, pp. 105-136.

Villaverde, V., Martínez Valle, R., 1992. Economía y aprovechamiento del medio en el Paleolítico de la región central del Mediterráneo español. In: Moure, A (Ed.), Elefantes, ciervos y ovicaprinos. Economía y aprovechamiento del medio en la Prehistoria de España y Portugal. Universidad de Cantabria, Santander, pp. 77-95.

Villaverde, V., Martínez Valle, R., Guillem, P.M., Fumanal, M.P., 1996. Mobility and the role of small game in the Paleolithic of the Central Region of the Spanish Mediterranean: a camparison of Cova Negra with other Palaeolithic deposits. In: Carbonell, E., Vaquero, M. (Eds.), The Last Neandetals, the First Anatomically Modern Humans: a Tale About Human Diversity. Cultural Change and Human Evolution: the Crisis at $40 \mathrm{Ka}$ BP. Universitat Rovira iVirgili, Tarragona, pp. $267-$ 288.

Villaverde, V., Aura, J.E., Barton, C.M., 1998. The Upper Palaeolithic in Mediterranean Spain: A review of current evidence. Journal of World Prehistory 12 , $121-198$.

Villaverde, V., Eixea, A., Zilhão, J., 2008. Aproximación a la industria lítica del Abrigo de la Quebrada (Chelva, Valencia). Treballs d'Arqueologia 14, 213-228.

Villaverde, V., Eixea, A., Rios, J., Zilhão, J., 2012. Importancia y valoración de la producción microlevallois en los niveles II y III del Abrigo de la Quebrada (Chelva, Valencia). Zephyrus 70, 13-32.

Walker, M.J., Gibert, J., López, M.V., Vincent Lombardi, A., Pérez-Pérez, A., Zapata, J., Ortega, J., Higham, T., Pike, A., Schwenninger, J.L., Zilhão, J., Trinkaus, E., 2008 Late Neandertals in Southeastern Iberia: Sima de las Palomas del Cabezo Gordo, Murcia, Spain. Proceedings of the National Academy of Sciences of the United States of America 105 (52), 20631-20636.

Walker, M.J., Lombardi, A.V., Zapata, J., Trinkaus, E., 2010. Neandertal mandibles from the Sima de las Palomas del Cabezo Gordo, Murcia, southeastern Spain. American Journal of Physical Anthropology 142 (2), 261-272.

Walker, M.J., Ortega, J., Parmová, K., López, M.V., Trinkaus, E., 2011a. Morphology, body proportions, and postcranial hypertrophy of a female Neandertal from the Sima de las Palomas, southeastern Spain. Proceedings of the National Academy of Sciences of the United States of America 108 (25), 10087-10091.

Walker, M.J., Ortega Rodríguez, J., López MArtínez, M.V., Trinkaus, E., 2011b. Neanderthal postcranial remains from the Sima de las Palomas del Cabezo Gordo, Murcia, southeastern Spain. American Journal of Physical Anthropology 144, 505-515.

Walker, M.J., Zapata, J., Lombardi, A.V., Trinkaus, E., 2011c. New evidence of denta pathology in 40,000-year-old Neandertals. Journal of Dental Research 90 (4), 428-432.

Walker, M.J., López Martínez, M.V., Ortega Rodrígañez, J., Haber Uriarte, M., López Jiménez, A., Avilés Fernández, A., Polo Camacho, J.L., Campillo Boj, M., García Torres, J., Carrión García, J.S., San Nicolas del Toro, M., Rodríguez Estrella, T. 2012. The excavation of the buried articulated Neanderthal skeletons at Sima de las Palomas (Murcia, SE Spain). Quaternary International 259, 7-21.

Walker, M.J., López Martínez, M.V., Carrión García, J.S., Rodríguez Estrella, T., San Nicolás del Toro, M., Schwenninger, J.L., López Jiménez, A., Ortega Rodrigáñez, J. Haber Uriarte, M., Polo Camacho, J.L., García Torres, J., Campillo Boj, M., Avilés Fernández, A., Zack, W., 2013. Cueva Negra del Estrecho del Río Quípar (Murcia, Spain): A late Early Pleistocene hominin site with an "AcheuloLevalloiso-Mousteroid” Palaeolithic assemblage. Quaternary International 294 135-159.

Wenzel, S., 2007. Neanderthal presence and behaviour in central and Northwestern Europe during MIS 5e. Developments in Quaternary Sciences 7, 173-193.

Williamson, B., 2005. Investigation of potential contamination on stone tools. Postexcavation contamination and measures for prevention. In: Torrence, R. Barton, H. (Eds.), Ancient Starch Research. Left Coast Press, Walnut Creek, p. 89.

Zilhão, J., Villaverde, V., 2008. The Middle Paleolithic of Murcia. Treballs d'Arqueologia $14,230-248$

Zilhão, J., Angelucci, D.E., Badal, E., d'Errico, F., Daniel, F., Dayet, L., Douka, K., Higham, T.F.G., Martínez Sánchez, M.J., Montes Bernárdez, R., Murcia, S., Pérez, C., Roldán, C., Vanhaeran, M., Villaverde, V., Wood, R., Zapata, J., 2010. Symbolic use of marine shells and mineral pigments by Iberian Neandertals. Proceedings of the National Academy of Sciences 107 (3), 1023-1028. 